\title{
Evaluating language revival policies of Russia's Finno-Ugric republics: policy impact and its limits
}

The paper evaluates language policies of the ethnic republics of Russia titled after the ethnic groups speaking Finno-Ugric languages in order to understand why the policies had limited impact on their sociolinguistic situations. This is an empirical-analytical study based on quantitative research that investigates within the framework of policy analysis the link between policy outputs and outcomes in order to test the hypothesis that changes in behaviour and attitudes can be traced back to the patterns of language management. The study produces a systematized set of data on measures taken to create the conditions for language knowledge, use and attitudes in the republics and searches for correlations among variables. The sources of quantitative data include legal and other official documents, accessible official statistics and available sociological and sociolinguistic surveys. Such a policy evaluation contributes to the theoretical understanding of the limits of the revivalist project pursued as a "top-down" public policy.

1. Introduction

2. Policy environment and policy scope

2.1. Development of the soviet language policy: historical context

2.2. Sociolinguistic condition of the titular groups of the Finno-Ugric ASSRs

2.3. Post-Soviet policy formation and adoption

3. Policy inputs and outputs

3.1. Evaluation of policy institutionalization and implementation

3.2. Creation of conditions in the domains of language use

4. Policy outcomes

4.1. Evaluation of policy outcomes

4.2. Indicators for policy outcomes

4.3. Sociolinguistic condition of the titular groups in Post-Soviet times

5. Policy impact

5.1. Evaluation of policy impact

5.2. Policy impact in the Finno-Ugric republics and its limits

6. Conclusion 


\section{Introduction}

In the early 1990s, Russia's ethnic republics posited "revival" of their titular languages as their language policy goal. While some republics took more practical efforts than others, it is generally recognized that the revivalist policies have neither reversed the language shift nor prevented further linguistic assimilation. The failure is true even for the far better protected Tatar language in Tatarstan, inter alia, because its prestige has not significantly increased in relation to Russian (see Gorenburg 2005). What was wrong with the policy? Was it not up to the task? Where and why did revivalist policies fail?

The purpose of the paper is to evaluate the effects of language policy in the Finno-Ugric republics of Russia in order to understand why revivalist policies with regard to the titular groups had such limited impact on their sociolinguistic situations. The cases of language policies of the Finno-Ugric republics are suitable for a comparative study because they cover a range of variables, while providing a sufficiently similar policy environment. The cases of language policies of Tatarstan and certain other Turkic republics, such as Bashkortostan or Sakha, are better known (and have also been studied comparatively; see, for example, Gorenburg 2003, 2005) and each is unique in its own way. This study takes the most illustrative data from Tatarstan to draw a baseline of what could have potentially been possible.

State language policy is a complex phenomenon. In studying it, Bernhard Spolsky $(2004,2009)$ used the stages approach and drew the distinction between language practices, language ideology and language planning (language management). Based on this distinction, in my research on language policy in the Finno-Ugric republics, I subsequently investigated, first, how practices and ideologies influenced language planning (Zamyatin 2015) and, second, why status planning became the main policy tool and what it implied (2013a, 2013b, 2013c), how the policy was institutionalized in language laws (2014b), and how it was implemented (2014c). In the last article mentioned, I evaluated how executive programs were implemented against their own goals and showed that, while the content of the state support was adequate vis-à-vis the revivalist goal, the extent of the support was insufficient. A general evaluation of policy implementation is still lacking.

The republics' ministries on nationalities affairs typically evaluated and reported annually on the implementation of their policies. However, these reports remained largely descriptive and present the data in absolute 
terms of the numbers of books published, language courses organized or events arranged (see Zamyatin 2014c). In addition, from time to time, the ministries commissioned some sociological and sociolinguistic research into different aspects of the ethnic and linguistic situation (1993-4, 1996, 2002, 2007 in Karelia; 1996, 2004, 2008-9 in Komi; 1994, 2001, 2003, 2011, 2012 in Mari El; 1991, 1994, 2010 in Mordovia; and 1994, 2000, 2003, 2007 in Udmurtia). However, the data were typically not interpreted in the context of the impact of language policy, probably because its accumulating lasting effects often remain indistinguishable over the short-term periods used for reporting. Similarly, individual studies conducted on language processes in republics remain descriptive and superficial with regard to the impact (see Klementiev 2013, Kondrashkina 2008, Williams et al. 2008, Vlasova 2016). Therefore, the actual impact of revivalist efforts on language practices and ideologies remains largely unknown.

The empirical rationale is based on my work done hitherto to finalize the study of the policy cycle in the Finno-Ugric republics of Russia. Evaluation is the last stage of the policy cycle and often concentrates on studying policy outcomes and impact. However, a complete evaluation should also assess the stages of policy formation and implementation. Policy formation determines which policy inputs and resources are raised. Policy implementation results in measures undertaken by agencies, policy outputs, and consequences for society in general, or policy outcomes. Impact is then the degree to which the outcomes observed are attributable to the outputs. A low impact is observed when the outcomes are rather attributable to social factors.

While it is often possible to study outputs using quantitative methods, it is more difficult to study outcomes, because these may be caused by factors other than outputs. Accordingly, I will apply François Grin's distinction of internal and external effectiveness evaluation to the study of outputs and outcomes, answering, respectively, the questions of whether the objectives were achieved and how they affected actual language use and attitudes (Grin 2003: 171-178). Grin suggested three principles of good policy: effectiveness, cost-effectiveness and democracy (Grin 2003: 91-96). In my evaluation, I will apply only the first principle of effectiveness as the most relevant to the given context, because the cost consideration was secondary in the top-down policy of the state that had not become a democracy. Impact reveals the policy effectiveness as the degree to which the goal was achieved. 
As part of the public policy analysis, I will conduct a systematic expert evaluation based on the quasi-experiment design when the policy effects on the target populations are measured comparatively across regions that are similar in many respects (Anderson 2010). What effects did the policies have? Policy is an independent variable that is controlled to test its effects on outcomes as the dependent variable. If the changes in inputs and outputs are reflected in the changes in outcomes, then the outcomes are to be attributed to the policies. I will compare the policy effects synchronically across the republics and diachronically across time periods along selected quantitative indicators based on the available statistical and survey data. The comparison across the republics is useful because, on the one hand, it makes it possible to test whether there is a link from the effects to policies based on the dissimilarity of cases and, on the other hand, to control for other variables based on the similarity of cases.

If the comparison reveals that the dissimilar patterns in inputs and outputs across republics in otherwise similar settings correspond to dissimilar patterns in outcomes, then the outcomes are to be attributed to the policies. Alternatively, if the pattern in outcomes across republics remain similar despite dissimilar policy inputs and outputs, then the outcomes are to be attributed to social factors external to policy. Policy inputs differed not only in the amount of the institutional and financial support for the revivalist policy but also in the level of political support. Inputs depended on the level of ethnic political representation (see $\mathrm{Za}$ myatin 2013c: 142-144). At the same time, the ethnic and socioeconomic situation of the republics is similar in most respects. Moreover, in the early 1990 s the republics adopted similar policies because titular elites borrowed from each other and advocated for the same ideas about language revival.

Timing provides another possibility to control for inputs and outputs. If in the early 1990 s some republics were determined in pursuing their revivalist policies, then first the decline in activities of national movements and later the change of the political regime in Moscow in the early 2000 s resulted in a narrowing of the scope of policy until the policies were $\mathrm{de} f a c$ to terminated in the early 2010 s (on the periodisation see Zamyatin 2016a). The development in individual republics was not as linear and depended on constellations of regional power. Thus, one could hypothesize that policy implementation in the 1990s and 2000 s should have had different policy effects (see Zamyatin 2014c: 231-232). 
In the first part of the paper, I will provide a historical overview of the developments of Soviet language policy and discuss the scope of measures in education and mass media provided for the titular groups of republics in its later period. Then, I will discuss the Soviet policy impact on some aspects of the sociolinguistic situation along such macrosociological indicators as demography and language retention rates and will further overview language knowledge and language use among the titular groups, based on data and evidence primarily from Lallukka (1990). I will further explore policy formation: how the accumulated trends in the sociolinguistic situation were identified in the post-Soviet times as policy problems, how these became the issues in the governmental agenda, what solutions were proposed, how the policy was formulated and what options passed in legislation, thereby determining the scope of the policy.

In the second part, I will first discuss the methods of evaluation of policy institutionalization and implementation. After that, I will study how policy outputs in the Finno-Ugric republics contributed to the creation of three conditions for language use: capacity, opportunity and desire to use the minority language in the spheres of public services and work environment, education and mass media, respectively. Based on the official data, I will assess such indicators as the numbers of bilingual road signs provided, pupils having access to native language learning, the numbers of printed matters published or the amount of time a language is used in TV and radio broadcasting.

In the third part, I will return to the discussion of the methods of evaluation focusing on policy outcomes. It would be most revealing to explore the diachronic changes in language knowledge and use in the private and public sphere, but consistent data is unavailable. Instead, I will present the data on the development in the sociolinguistic situation of the republics in post-Soviet times and the policy effects on their titular communities along the same indicators as for the Soviet period. In addition, I will separately discuss language attitudes. While it may take a generation to see a change in patterns of language knowledge and some years for those of language use, language attitudes can change very quickly, especially in times of rapid social transformations, and can thus serve as a more sensitive indicator of policy impact.

I will mostly use semi-official surveys regularly conducted by the republics' research institutes in the system of the Russian Academy of Sciences. These representative surveys are typically uniformly conducted over time 
periods and relatively reliable in methodological terms. To spare space, I will not provide the details on their methodologies, which are described in the sources I quote. I will also use the only existing cross-regional survey conducted across the Finno-Ugric regions of Russia in 2007 (see Finnougorskie narody 2008). At the end of each subsection, I will focus on young people as the most important policy target group.

In the fourth part, I will discuss the methods of impact evaluation and assess what impact the policies had in the Finno-Ugric republics of Russia. Suzanne Romaine has emphasized that the evaluating the impact of language policy is complicated by a lack of straightforward casual connection between types of policy and language maintenance and shift, because language policy is not an autonomous factor and much depends on the cultural context (Romaine 2002). I will show how the outputs and outcomes correlate along selected indicators. This does not reveal causation but makes it possible to put forth only probabilistic arguments about impact.

In the conclusion, I will hypothesize as to why the policy might have had a limited impact. Bernhard Spolsky's "top-down" perspective on language policy as that pursued by the state was criticized for not taking into account a "bottom-up" grass-roots perspective (Johnson 2013). Earlier, I have argued elsewhere that studying language policy of Russia with its central role of the state from the top-down perspective provides an adequate descriptive account because this is exactly the way it was pursued (see Zamyatin 2014a: 43-47). However, the current study of the impact also reveals the limits of such a policy that could not reverse the processes it was designed to overcome. Therefore, the study results also have some normative implications and provide new evidence for the importance of a bottom-up grass-roots perspective.

\section{Policy environment and policy scope}

\section{I. Development of the Soviet language policy: historical context}

It was the affirmative action of the Soviet central government towards minority nationalities that ensured their national development through the national delimitation and the creation of national territorial units. The Union of Soviet Socialist Republics (USSR) became nominally a federation composed of union republics (SSRs), the state's first-layer units, named after their majority ethnic groups ("titular peoples"). The largest 
among them was the Russian Soviet Federative Socialist Republic (RSFSR). Autonomous Soviet Socialist Republics (ASSRs) became the second-layer units in the federation, territorially within and administratively subordinate to the RSFSR. Due to the mixed character of ethnic settlement, the national delimitation faced difficulties also within the RSFSR. In the Volga region, the Bashkir ASSR was the first to be created, in 1919, followed by the Tatar ASSR in 1920. The Tatars were by the far largest group concentrated within Russia and even aspired for the status of SSR for their republic, although they did not succeed in achieving this (see Zamyatin 2013a: 126-127).

The industrialization and collectivization of the early Soviet period destroyed traditional lifestyles and embroiled also the peoples speaking Finno-Ugric languages in the wave of modernization and urbanization. In 1920, autonomous regions were for the first time created for various smaller ethnic groups, including the Finno-Ugric peoples in Northwestern Russia and in the Volga region on the territories adjacent to the Tatar ASSR. In 1934-1936, these regions were upgraded to ASSRs. The national state-building process was conjoined with the early Soviet policy of "nativization", according to which the presence of non-Russians in the communist party and the state apparatus was to be strengthened. This resulted in the emergence of the first generation of national intellectuals (Zamyatin, forthcoming).

These processes were accompanied by unprecedented language planning efforts that encouraged the expansion of the official use of autochthonous languages in the public sphere of the newly created autonomies. The dissemination of these languages throughout the state apparatus in the Finno-Ugric ASSRs was never achieved due to some objective difficulties in corpus planning but also due to the short period until the subsequent policy change and the negative attitudes of the local Russians. At the same time, the accomplishments of early Soviet language planning were remarkable in terms of the spread of literacy and printed matters, as well as the creation of mass media and national schools operating in those languages.

The titular language was the language of instruction for $16.5 \%$ of schoolchildren in Karelia (along with 10.6\%, who were instructed in the titular "Karelian and another" language, presumably Russian), 58.8\% in Komi (and 24.6\% in two languages), 29\% in Mari (and 21.7\% in two languages), $34.3 \%$ in Mordovia, $19.3 \%$ in Udmurt (and $20.7 \%$ in two languages) in Udmurtia and $46.8 \%$ in Tatarstan, the rest having Russian as their language of instruction in all republics. The data are for the academic year 1938-1939, 
when the peak in opening national schools has already passed (Kulturnoe stroitelstvo 1940: 76-77). The immersion model was in use when more titular children received native language instruction in primary school, but their share dropped in secondary school, except in Mordovia, with its stable provision. Thus, when compared with the data of the 1939 population census, practically all titular schoolchildren had instruction in their native language; however, Russian started to supplant the native language of instruction after the introduction of its compulsory study since 1938.

In 1938, 30,300 book titles were published in Russian with an annual edition of 545,730 thousand exemplars. The corresponding figures were 89 titles and 546 thousand in Karelian, 156 titles and 723 thousand in Komi, 112 and 524 thousand in Mari, 161 and 1,435 thousand in Mordvin, 66 and 878 thousand in Udmurt, and 403 and 5,900 thousand in Tatar. Altogether 6,360 newspapers were published in Russian with an annual edition of about 5,878,500 thousand exemplars. The corresponding figures were six for Karelian and four for Finnish, with about 2,700 thousand exemplars together, 17 newspapers and 4,00o thousand in Komi, 16 newspapers and 4,500 thousand in Mari, ten and 5,00o thousand in Mordvin, 21 and 8,400 thousand in Udmurt, and 124 and 52,00o thousand in Tatar. A total of 1,406 journals were published in Russian with the annual edition of 238,200 thousand exemplars. The corresponding figures were one journal and 25 thousand in Karelian, one journal and 13 thousand in Komi, one and two thousand in Mari, four and 18 thousand in Mordvin, one and six thousand in Udmurt, and 11 and 662 thousand in Tatar (Kulturnoe stroitelstvo 1940: 214-215, 221).

Since the mid-1930s, the Russian language started to be promoted among non-Russians, initially justified by practical considerations such as the need for a common language. Starting in the late 1930s, the authorities began to emphasize the dominant position of ethnic Russians as well as the Russian culture and language. The repression of national intelligentsia followed as part of the Stalinist purges. In the following decades, the goal of Soviet nationalities policy shifted from the promotion of non-Russian nationalities towards the creation of a unified Soviet people, which implied the incremental assimilation of minorities.

As a result of population mixing and assimilation, ethnic Russians started to outnumber the titular groups in the Finno-Ugric ASSRs, while significant portions of titular populations were encouraged by Soviet migration policy to out-migrate to other regions. By 1989, about two thirds of 
Mordvins (and also Tatars), half of Mari, a third of Udmurts and Karelians and up to a sixth of Komi lived outside their titular ASSRs. Notably, language teaching and printed matters were typically provided only in titular regions. Their volumes depended de facto on the status of ethnic groups in the Soviet hierarchy, where languages were classified as those of the SSRs, ASSRs, etc. Since the 1960s, the Soviet state, under a laissez-faire policy, began to withhold support for smaller languages, and the positions of the titular languages of the ASSRs deteriorated.

The major vehicle of assimilation of non-Russians in the RSFSR was the gradual substitution of instruction in the native languages with instruction in Russian after enforcement by the 1958 education reform of free choice in language learning (see Zamyatin 2012b). In Karelia, Karelian was never introduced as the medium of instruction, inter alia, due to "Finnicization" (see Klementiev 2013: 15-16). In the aftermath of the reform, native instruction in the republics was stopped in Komi and Udmurt and was retained in Mari and the Mordvin languages only in some rural schools.

Children's access to the learning of their native language as a subject also significantly decreased. From the mid-1970s to the mid-1980s, the number of children learning the Komi language as a subject declined from about 25,000 to 15,000 , the latter figure representing only about a quarter of the Komi pupils in the republic. From the early 1970s to the late 1980s, the number of children learning the Mordvin languages dropped from 77,000 to 24,000 , the latter figure being perhaps less than $15 \%$ of all Mordvin pupils. From the late 1950 s to the mid-1980s, the number of children learning the Udmurt language as a subject declined from about 32,000 to 29,000, the latter figure being about a third of Udmurts of school age (see Lallukka 1990: 183-191.) With the shift in languages of instruction from the native language to Russian, which reached its fullest extent in the 1970s, an entire generation of parents emerged who had never had native language instruction and were fluent in Russian (Zamyatin 2012c: 89-90).

The production of printed matters in the Finno-Ugric languages has been carried out almost exclusively by publishing houses of the titular ASSRs. The use of these languages in publishing also significantly decreased especially in the post-war decades. Karelian remained a language without a written form. In 1946-1955, average annual numbers of titles of books and brochures published in Komi was 61.1, in Mari 88.2, in the Mordvin languages 81.4 and in Udmurt 59.1. In 1976-1985, the corresponding figures were 21.9 in Komi, 42.6 in Mari, 46.6 in the Mordvin 
languages and 27.9 in Udmurt. According to a rough estimation, the average annual numbers of titles of books and brochures dropped by half during this period. At the same time, the numbers and circulations of journals and newspapers remained relatively stable, albeit quite low in absolute terms (see Lallukka 1990: 191-194). By the time of the USSR's collapse, the titular languages had become stigmatized de facto minority languages that were practically not used at all in official contexts except for symbolic purposes.

\subsection{Sociolinguistic condition of the titular groups of the Finno-Ugric ASSRs}

The policy developments had their impact on the sociolinguistic situation and contributed to ethnic assimilation and extensive language shift from non-Russian languages to Russian in the titular republics but especially elsewhere, because many members of the titular groups out-migrated to other regions. Ethnic assimilation during the Soviet times is well documented and could be followed, for example, based on the data of Soviet population censuses. Language shift, however, remained less discernible (see Table 1 on the following page).

There are some problems with the Soviet census data on ethnicity and language. In particular, the data on language retention rates are not very informative because they were based on the subjective interpretation of the respondents and likely underestimate the extent of linguistic assimilation. The term "Native language" began to be interpreted in the later Soviet population censuses not as one's mother tongue but as the language of one's ethnic affinity, thereby avoiding tension between one's identity and a lack of language knowledge. For that reason, the data on the command of a language and on actual language use are more illustrative of the sociolinguistic processes (see Lallukka 1990: 71-82).

First of all, during the late Soviet decades, titular groups reached a high level of national language-Russian bilingualism patterns, while local Russians remained practically monolingual. Seppo Lallukka has demonstrated how different patterns of bilingualism contributed to the language shift as the numbers of "native monolinguals" and "unassimilated bilinguals" dropped and the numbers of "assimilated bilinguals" and "assimilated monolinguals" grew steadily (see Lallukka 1990: 194-207). Lallukka found a correlation between urbanization and the processes of language shift and assimilation. 


\begin{tabular}{|l|r|r|r|r|r|r|}
\hline Republic & Komi & \multicolumn{1}{|c|}{ Mari } & Mordovia & Udmurtia & Karelia & Tataria \\
\hline 1. Total population of the republic (thousands) \\
\hline Census 1939 & 319 & 579 & 1,188 & 1,219 & 486 & 2,915 \\
\hline Census 1959 & 816 & 648 & 1,002 & 1,337 & 651 & 2,850 \\
\hline Census 1970 & 965 & 685 & 1,030 & 1,418 & 713 & 3,131 \\
\hline Census 1979 & 1,118 & 703 & 990 & 1,494 & 736 & 3,435 \\
\hline 2. Titular group (thousands) \\
\hline Census 1939 & 231 & 273 & 405 & 480 & 109 & 1,422 \\
\hline Census 1959 & 245 & 279 & 358 & 476 & 85 & 1,345 \\
\hline Census 1970 & 276 & 299 & 365 & 484 & 84 & 1,536 \\
\hline Census 1979 & 280 & 307 & 339 & 480 & 81 & 1,641 \\
\hline 3. Share of the titular group in the total population of the republic (\%) \\
\hline Census 1939 & $72.5 \%$ & $47.2 \%$ & $34.1 \%$ & $39.4 \%$ & $23.2 \%$ & $48.8 \%$ \\
\hline Census 1959 & $30.1 \%$ & $43.1 \%$ & $35.7 \%$ & $35.6 \%$ & $13.1 \%$ & $47.2 \%$ \\
\hline Census 1970 & $28.6 \%$ & $43.7 \%$ & $35.4 \%$ & $34.2 \%$ & $11.8 \%$ & $49.1 \%$ \\
\hline Census 1979 & $25.3 \%$ & $43.5 \%$ & $34.3 \%$ & $32.1 \%$ & $11.1 \%$ & $47.6 \%$ \\
\hline 4. Report knowledge of their titular native language in the republic (\%) & \\
\hline Census 1959 & $93.8 \%$ & $97.8 \%$ & $97.3 \%$ & $93.2 \%$ & $80.9 \%$ & $98.9 \%$ \\
\hline Census 1970 & $86.7 \%$ & $95.8 \%$ & $96.2 \%$ & $87.7 \%$ & $71.7 \%$ & $98.5 \%$ \\
\hline Census 1979 & $80 \%$ & $93.7 \%$ & $94.3 \%$ & $82.3 \%$ & $61.2 \%$ & $97.7 \%$ \\
\hline 5. Report knowledge of their native language in the RSFSR as a whole (\%) \\
\hline Census 1939 & $95.3 \%$ & $98.7 \%$ & $88.6 \%$ & $97.3 \%$ & $90.6 \%$ & $97.7 \%$ \\
\hline Census 1970 & $83.4 \%$ & $91.9 \%$ & $79.7 \%$ & $83.5 \%$ & $63.9 \%$ & $90.5 \%$ \\
\hline Census 1979 & $76.9 \%$ & $87.7 \%$ & $74.6 \%$ & $77.6 \%$ & $56.5 \%$ & $88.1 \%$ \\
\hline
\end{tabular}

Table 1: Dynamics in absolute numbers and shares of the titular groups in relation to the total population of the Finno-Ugric Republics and their language retention rates (census data)

According to the data obtained by Lallukka, the knowledge of Russian improved to the point that it generally started to be better than the knowledge of one's native language. His data on oral and literary competence and language preferences suggested that such competence was more developed in Russian and people were yielding to preferring this language when it was necessary to use their literary skills. People's skills in Russian 
improved when it came to speech, reading and writing, while reading and writing in one's native language had notably worsened, partly due to the workings of the school system and the availability of printed materials. The data on the Komi demonstrate that by the early 1980s, they knew Russian better than their native language (see Table 2).

\begin{tabular}{|l|r|r|r|r|r|r|}
\cline { 2 - 8 } \multicolumn{1}{c|}{} & \multicolumn{1}{c|}{ Speech } & Reading & Writing & Speech & Reading & Writing \\
\cline { 2 - 8 } & \multicolumn{2}{l}{$\begin{array}{l}\text { Have a free command of the } \\
\text { language in the designated } \\
\text { component }\end{array}$} & \multicolumn{2}{l}{$\begin{array}{l}\text { Language preferences in } \\
\text { regard to the components }\end{array}$} \\
\hline Komi & 96.8 & 67.7 & 64.4 & 61 & 10.1 & 13.5 \\
\hline Russian & 85.3 & 83.8 & 82.7 & 19.3 & 62.8 & 60.7 \\
\hline Both equally & n/a & n/a & n/a & 19.7 & 27.1 & 25.8 \\
\hline
\end{tabular}

Table 2: Command and preferential use of the Komi language and Russian by components of the language: rural Komi in 1981 (\%, adapted from Lallukka 1990: 214)

In the data, over $80 \%$ of respondents claimed to command Russian freely in the three components, while for Komi, the reading and writing skills were less developed. Accordingly, most Komi preferred to read and write in Russian, which turned their native language into a spoken vernacular. This also corresponded to the data on the patterns of reading books and periodicals. Adult Komi showed the best competency in their native language, while the young and old generations lagged far behind. Lallukka attributes this outcome to the rise and fall of native-language education in the ASSRs. His conclusion is that Russian had become the language of the written word for the broad masses of titular groups (Lallukka 1990: 214216). The data on reading habits are illustrative of this fact (see Table 3).

Regarding language use in one's family, Russian had penetrated family life in such a way that, while the bulk of adult Mari still used their native language in communication with parents and spouses, only a portion did so in communication with their children (see Table 4).

Further, a strong swing to Russian occurred during the decade across generations but especially among children. Language use strongly correlates with a person's place of residence: in 1985, about $80 \%$ of parents in the capital city of Yoshkar-Ola spoke Russian to their children, while in the villages only $5-6 \%$ did so. Therefore, the data show that a considerable 


\begin{tabular}{|l|r|r|l|r|r|}
\cline { 2 - 6 } \multicolumn{1}{c|}{} & \multicolumn{1}{c|}{ Rural } & Urban & \multicolumn{2}{l|}{$\begin{array}{l}\text { Urban: } \\
\text { Creative } \\
\text { Intelligentsia }\end{array}$} & \multicolumn{2}{l|}{ Rural } & \multicolumn{1}{c|}{ Urban } \\
\cline { 2 - 7 } \multicolumn{1}{c|}{ Reading of periodical publications } & \multicolumn{2}{c|}{ Reading of books } \\
\hline Only Russian & 70.8 & 88.2 & 18.5 & 36.3 & 45.9 \\
\hline $\begin{array}{l}\text { Russian and Erzia/ } \\
\text { Moksha }\end{array}$ & 26.3 & 11.3 & 81.5 & 46.5 & 42.2 \\
\hline Only Erzia/Moksha & 2.9 & 0.5 & 0 & 17.2 & 8.9 \\
\hline
\end{tabular}

Table 3: Reading of periodical publications and books by Mordvins in the Mordvin ASSR in 1973-74 (\%, adapted from Lallukka 1990: 215-216).

\begin{tabular}{|c|c|c|c|c|c|}
\hline & $\begin{array}{l}\text { With One's } \\
\text { Parents }\end{array}$ & $\begin{array}{l}\text { With One's } \\
\text { Spouse }\end{array}$ & $\begin{array}{l}\text { With One's } \\
\text { Children }\end{array}$ & $\begin{array}{l}\text { of School } \\
\text { Age }\end{array}$ & $\begin{array}{l}\text { of Preschool } \\
\text { Age }\end{array}$ \\
\hline $\begin{array}{l}\text { 1973: } \\
\text { Russian }\end{array}$ & 4.6 & 8.1 & 14.8 & $\mathrm{n} / \mathrm{a}$ & $\mathrm{n} / \mathrm{a}$ \\
\hline $\begin{array}{l}\text { 1973: } \\
\text { both }\end{array}$ & 15.2 & 20.9 & 19.3 & $\mathrm{n} / \mathrm{a}$ & $\mathrm{n} / \mathrm{a}$ \\
\hline $\begin{array}{l}\text { 1973: } \\
\text { Mari }\end{array}$ & 80 & 70.8 & 65.6 & $\mathrm{n} / \mathrm{a}$ & $\mathrm{n} / \mathrm{a}$ \\
\hline $\begin{array}{l}\text { 1985: } \\
\text { Russian }\end{array}$ & 8.2 & 16.4 & 33.4 & 31.5 & 35.1 \\
\hline $\begin{array}{l}\text { 1985: } \\
\text { both }\end{array}$ & 17.2 & 22 & 23.2 & 23.7 & 22.5 \\
\hline $\begin{array}{l}\text { 1985: } \\
\text { Mari }\end{array}$ & 74.1 & 60.4 & 42.3 & 43.4 & 41.4 \\
\hline
\end{tabular}

Table 4: Language used in communication by adult Mari with members of their family (\%, adapted from Lallukka 1990: 212)

portion of families failed to transmit their language to the next generation (Lallukka 1990: 211-213).

Moreover, the native languages were much less often used at work or at public meetings than at home, and over the decades, this gap widened. The data show that most rural dwellers spoke their native language at home and more than half also spoke it at work, which Seppo Lallukka attributed to the relative ethnic homogeneity of the villages. The relevance of the latter factor could be seen, for example, in patterns of native language use at work among Komi lumberers, which depended on whether their share of 


\begin{tabular}{|c|c|c|c|c|c|c|c|c|c|}
\hline \multirow[t]{3}{*}{ Republic } & \multicolumn{2}{|c|}{ Mordvins } & \multicolumn{3}{|c|}{ Udmurts } & \multicolumn{4}{|l|}{ Komi } \\
\hline & Rural & Urban & Rural & Urban & Rural & lumber A & lumber B & village & lumber \\
\hline & $1973-4$ & $1973-4$ & 1968 & 1968 & 1979 & $1970-1$ & $1970-1$ & 1981 & 1981 \\
\hline \multicolumn{10}{|c|}{ Native language } \\
\hline At home & 91.6 & 21.7 & 78 & 15 & 73 & 27.6 & 70 & 71.2 & 19.3 \\
\hline At work & 61.8 & 1.8 & 62.7 & 5.3 & 48.4 & 4.7 & 13.6 & 36.3 & 0.5 \\
\hline $\begin{array}{l}\text { At public } \\
\text { meetings }\end{array}$ & 31.9 & 1.1 & 47.1 & 6.9 & 25.2 & $\mathrm{n} / \mathrm{a}$ & $\mathrm{n} / \mathrm{a}$ & $\mathrm{n} / \mathrm{a}$ & $\mathrm{n} / \mathrm{a}$ \\
\hline \multicolumn{10}{|c|}{ Russian and native language } \\
\hline At home & 5.3 & 26.5 & 9.2 & 24.5 & 17.6 & 20.9 & 12.7 & 21.4 & 38.2 \\
\hline At work & 32.2 & 26.5 & 22.8 & 16.8 & 36.1 & 22.6 & 26.6 & 54.1 & 48.2 \\
\hline $\begin{array}{l}\text { At public } \\
\text { meetings }\end{array}$ & 26.1 & 3.8 & 22.3 & 3.6 & 21.3 & $\mathrm{n} / \mathrm{a}$ & $\mathrm{n} / \mathrm{a}$ & $\mathrm{n} / \mathrm{a}$ & $\mathrm{n} / \mathrm{a}$ \\
\hline \multicolumn{10}{|l|}{ Russian } \\
\hline At home & 3.1 & 51.8 & 12.8 & 59.6 & 9.1 & 48.6 & 16 & 7.4 & 42.5 \\
\hline At work & 5.9 & 71.7 & 14.5 & 77.9 & 15.1 & 72.5 & 59.5 & 9.3 & 51.3 \\
\hline $\begin{array}{l}\text { At public } \\
\text { meetings }\end{array}$ & 42 & 95.1 & 30.6 & 89.5 & 52.6 & $\mathrm{n} / \mathrm{a}$ & $\mathrm{n} / \mathrm{a}$ & $\mathrm{n} / \mathrm{a}$ & $\mathrm{n} / \mathrm{a}$ \\
\hline
\end{tabular}

Table 5: Use of native languages and Russian by Mordvins, Udmurts and Komi in the titular republics in various domains of daily life (\%, adapted from Lallukka 1990: 208)

the workers was less than a quarter (lumberers A) or almost a half (lumberers B, see Table 5).

However, the dynamics of native language use at work during the decade in Udmurtia was that the number dropped to less than half even in rural areas. Moreover, Russian became the dominant language of sociopolitical life in villages and was most often used at public meetings. In urban areas, Russian had become the sole medium of communication in all three domains for the majority of Mordvins and Udmurts. Lallukka demonstrated that ethnic intermarriage was a factor that strongly affected domestic language behaviour (see Lallukka 1990: 207-211). Further, the use of Russian increased in correlation with the level of education: white-collar and highly skilled workers showed an increased use and competency in Russian, while unskilled laborers were more likely to use native language. 
The language shift was much more advanced among the young cohorts, which can be seen very well in the data on rural Karelians (see Table 6).

\begin{tabular}{|c|c|c|c|c|c|c|c|c|}
\hline & Age group & $16-19$ & $20-24$ & $25-29$ & $30-34$ & $35-39$ & $40-49$ & $>50$ \\
\hline \multirow{3}{*}{$\begin{array}{l}\text { Knowledge } \\
\text { of Karelian }\end{array}$} & Fluent & 83.5 & 72.7 & 87.4 & 96.2 & 95.1 & 96.9 & 96.6 \\
\hline & $\begin{array}{l}\text { Understand, } \\
\text { express }\end{array}$ & 8.9 & 17.2 & 9.6 & 2.1 & 1.8 & 2.9 & 2.4 \\
\hline & $\begin{array}{l}\text { Understand, } \\
\text { do not } \\
\text { speak }\end{array}$ & 7.6 & 10.1 & 3 & 1.7 & 3.1 & 0.2 & 1 \\
\hline \multirow[t]{3}{*}{ Fluent } & Karelian & 39.1 & 31.7 & 57.3 & 58.8 & 55.9 & 75.3 & 75 \\
\hline & Russian & 40 & 39.5 & 20.9 & 18.9 & 12.8 & 7.4 & 13.7 \\
\hline & Both & 20.9 & 28.8 & 21.8 & 22.3 & 21.3 & 17.3 & 11.3 \\
\hline \multirow{3}{*}{$\begin{array}{l}\text { Native } \\
\text { language }\end{array}$} & Karelian & 64.2 & 68.6 & 84.9 & 85.9 & 90.3 & 94.1 & 96.5 \\
\hline & Russian & 25.4 & 26.4 & 12.9 & 10.2 & 9 & 4.3 & 3.2 \\
\hline & Both & 4.4 & 4.2 & 2.2 & 3.9 & o & 0.6 & o \\
\hline \multirow[t]{3}{*}{$\begin{array}{l}\text { Speak at } \\
\text { home }\end{array}$} & $\begin{array}{l}\text { Karelian } \\
\text { only }\end{array}$ & $45 \cdot 3$ & 31.3 & 46.9 & 37.3 & 32.3 & 44.2 & 56.8 \\
\hline & $\begin{array}{l}\text { Russian } \\
\text { only }\end{array}$ & 31.9 & 36.1 & 23.2 & 27.2 & 25.2 & 19.6 & $14 \cdot 3$ \\
\hline & Both & 22.8 & 33.5 & 29.9 & 34.9 & 42.5 & 34.4 & 25.6 \\
\hline \multirow[t]{3}{*}{$\begin{array}{l}\text { Speak at } \\
\text { work }\end{array}$} & $\begin{array}{l}\text { Karelian } \\
\text { only }\end{array}$ & 8.8 & 4.5 & 17.3 & 12.8 & 11.2 & 22 & 26.5 \\
\hline & $\begin{array}{l}\text { Russian } \\
\text { only }\end{array}$ & 58.3 & 67.5 & 45.2 & 47.1 & 46.8 & 34.5 & 25 \\
\hline & Both & 32.9 & 26.9 & 32.8 & 39.3 & 41.3 & 42.8 & 45.9 \\
\hline
\end{tabular}

Table 6: Language knowledge and use by the age cohorts of Karelians in rural areas (\%, adapted from Klementiev 2013: 18)

In the case of the Karelians, an important factor at play was the absence of schools offering the native language as the language of instruction. Language shift among the Karelians was more advanced than in other republics, but the same processes were also characteristic of the other titular groups, for example, among rural Mordvins (see Vavilin 1989). Based on the observed processes, Lallukka concludes that Russian became the language used in all domains, while the prestige and the scope of the social functions of the titular languages narrowed considerable especially during 
the last Soviet decades, leaving them mostly in the private sphere (see Lallukka 1990: 216).

The mechanism of how the ethnic groups and their languages became stigmatized lies in the social structure that is the system of socioeconomic stratification. Scholars typically distinguish between the vertical and horizontal types of ethnic and social stratification, where either one group is subordinated to another or the groups form segments across social divisions (see Horowitz 1985). Subordination manifests itself in varying access to higher education and white-collar jobs, as well as in socioeconomic inequality. In segmented societies, the ethnic identity of an individual does not correspond with his or her social status. In reality, both stratification and segmentation typically co-exist. In Russia, the populations of ethnic regions represent a variety of patterns of stratification. In some republics, for example, in Tatarstan or Sakha, the titular group and local Russians had roughly similar employment structures and competed for jobs. In other republics, either the titular groups or ethnic Russians were overrepresented in high-status jobs (see Zamyatin 2016c: 223).

By the start of the new era, the ethnic and socioeconomic situation in the Finno-Ugric Republics had become characterized by the vertical type of stratification, as social differentiation between urban and rural dwellers largely overlapped with the ethnic cleavage between ethnic Russians and the titular groups. This type of ethnic stratification gives ground for instances of prejudice and discrimination typically expressed through verbal abuse and denial of certain social resources, such as equal access to education. Despite the massive migration of titular populations to the cities during the Soviet times, no significant urban segments of titular groups emerged, due to their steady but gradual arrival. Their adaptation and acculturation strategies in the predominantly Russian urban surroundings have undermined ethnic solidarity among them and contributed to the blurring of ethnic boundaries on the way to assimilation and the spread of the perception of Russian as the language of socioeconomic advancement (see Zamyatin 2016c: 222-224).

\subsection{Post-Soviet policy formation and adoption}

I study language planning based on the stages approach, which distinguishes a series of stages from policy formation and policy adoption to 
implementation and evaluation (see Anderson 2010). Policy formation includes the stages of problem identification, agenda-setting and policy formulation that structure this section. Policy formation takes place within a certain policy environment. To characterize the environment, I borrow from the concepts of the advocacy coalition framework, the multiple streams framework and the punctuated equilibrium framework (see Sabatier 2007).

A policy venue is characterized by some set of actors (see chapter 6 in Sabatier 2007). Policy actors are not only official policymakers, the central and republics' authorities, but also non-governmental participants. During the political transition in the USSR, the policy venue changed, bringing in new political participants. Both the masses and elites participated in shaping the policies. Mass national movements emerged as organized efforts to achieve the attributes of a fully-fledged nation. Newly created political parties and interest groups formed as national organizations pursued their visions on the issue. Pressure groups within the elites formed into what I conceptualize as titular and Russian elite segments. Within the segments, advocacy coalitions (see chapter 7 in Sabatier 2007) of cultural and political elites emerged, the former typically being in creative professions such as writers, scholars and teachers, and the latter "national cadres" of the Communist Party of the Soviet Union (CPSU) and the state apparatus or nomenklatura (Zamyatin 2014a: 60-64).

Demands for policy actions stem from the identification of problems in the environment. The policy image is the way to conceptualize the set of problems and solutions. The Soviet industrialization policy was conjoined with mass population transfers between republics and resulted in major demographic change, particularly in the Soviet Baltic Republics, where the shares of newcomers rapidly increased. One effect of the change was that the Russian language began to supplant the local languages in the public sphere and power corridors. With the progression of perestroika from the mid-198os, intellectuals in the SSRs and ASSRs identified this condition as the problem and, with the introduction of publicity (glasnost), dared to spread their concerns in the mass media. The intellectuals initiated the creation of national organizations to lead the emerging popular movements in the SSRs and ASSRs. Under pressure from the national movements, the CPSU republics' central committees, headed by national cadres, advocated for the inclusion of the problem as an issue in the policy agenda and urged the central government to act. 
In 1988, the Estonian Communist Party Central Committee presented to the CPSU the demand to guarantee the sovereign rights of the SSRs, including a guarantee of the designation of their state languages. The demand ignored, the Estonian SSR first unilaterally passed in November 1988 its declaration of state sovereignty and then amended its constitution in December 1988 and passed the 1989 language law, with both, among other things, designating its titular language as its sole state language. The Latvian and Lithuanian ASSRs followed suit. These SSRs designated the titular languages as their sole state languages, officially because it was assumed that Russian would be the official language of the USSR. The status of state language combines two functions: the symbolic function of national language and the practical function of official language (Zamyatin 2014a: 16-18). During 1989 and by the spring of 1990, all SSRs except the RSFSR had passed their language laws. Among the actual reasons might have been concerns that a co-official status of Russian and the republic's language would not prevent the shrinking in official use of the latter and the conviction that only sole state language status would enhance its practical promotion (Zamyatin 2013a: 127-128).

To head the process, the CPSU in its September 1989 Platform on the Nationalities Policy suggested "advisability of the recognition of the state languages of the nationalities that gave names to the SSRs and ASSRs". It also recommended that the status of Russian as the nation-wide state language should be enshrined in law and that it should function on equal-inrights footing with the state languages of the republics. The USSR language law of April 1990 provided the legal basis for this and designated Russian as the USSR's official language. The RSFSR was the last among the SSRs to pass its sovereignty declaration in June 1990, albeit without designating state languages. After this, the sovereignization and the official recognition of languages proliferated in a "cascade effect", which also extended to the level of ASSRs. Thus, the "parade of sovereignties" of 1990 opened the "occasions window" for the official designation of languages also in autonomies of the RSFSR (Zamyatin 2013a: 129-136). This way, the streams of problem, policy and politics met in a nexus linking a range of policy alternatives to address the problems raised under the conditions of political transition (for the multiple-stream theory, see chapter 2 in Sabatier 2007). 


\subsection{The interpretation of sociolinguistic trends as problems}

The policy environment encompasses both the political culture and socioeconomic conditions. Gabriel Almond and Sidney Verba (1963) distinguish between parochial, subject and participant types of political culture. In a parochial political culture, citizen participation in policy formation is essentially non-existent. In a subject political culture, citizens may believe that they can do a little to influence public policy. In a participant political culture, citizens actively take part in politics.

In Russia's republics, there was a mix of a parochial and a subject political culture with small fragments of participant culture. Truly mass national movements typically emerged in the republics with significant urbanized titular populations in large capital cities. In the late 1980s, national organizations were also created in the Finno-Ugric ASSRs, but these were relatively weak and were never able to initiate mass ethnic mobilization, except for a short time in the Mari Republic (see Zamyatin 2016c: 224). It was arguably the combination of the political culture with the vertical type of stratification that predetermined a low level of popular support for nationalism in the Finno-Ugric republics (on measuring support, see Gorenburg 2003: 118-119, also subsection 4.3.3 below).

In the view of Thomas Dye (2001), public policy reflects the values, interests and preferences of the governing elite. He argues that even in a democracy like the United States, public policy is made from the top down, not from the bottom up. It was elite politics that mattered more than mass politics also in the latter category of ASSRs. The creation of national movements themselves in these republics was typically inspired "from above" because the republics' elites needed their existence to justify their claims for the republics' self-governance vis-à-vis the Kremlin (Zamyatin 2013a).

In the name of the titular peoples, national organizations expressed their dissatisfaction with the current condition when the data were publicised about the shift from the titular languages to Russian and the ethnic assimilation of non-Russians as well. The publication of the data of the 1989 population census added to public awareness of the problems. The organizations defined this condition as a problem, publicly articulated it and raised linguistic and cultural demands from the republics' governments to address the problem.

For a condition to be converted into a problem, people must have some criterion or standard by which the troubling condition is judged to be 
unacceptable (Anderson 2010: 81). The Kremlin launched perestroika as an attempt to return to the genuine Leninist course. In this context, the conditions of language loss and ethnic assimilation were perceived as unjust and unacceptable by the standards of the early Soviet nationalities policy with its affirmative action approach. The organizations were quasi-representative bodies that since 1991 arranged the titular "people's congresses". The congresses claimed to represent the titular peoples and also raised political demands. Enjoying support of the republics' authorities, they had enough legitimacy and leverage to focus public attention on the problem.

\subsubsection{Raising the issue on the policy agenda}

The economic crisis of the early 1990 s exposed social problems connected to unequal economic and educational opportunities across ethnic groups. However, national organizations in the Finno-Ugric ASSRs failed to link the problem of a disadvantaged socioeconomic situation of the titular groups with political demands and to gain public support (Zamyatin 2016c: 226). With a low level of popular mobilization, the masses remained largely indifferent to the problems raised. Yet, agenda setting in the ASSRs was also a top-down process. There was a vocal public discussion in mass media, because the rise of nationalism and separatism in the SSRs and ASSRs questioned the very existence of the state and, thus, the position of the elites. The public debates about language were embedded in these processes, as could be seen in the discourse analysis of mass media (see Zamyatin 2018b).

Agenda setting involves both a conflict and collaboration. As the Soviet ideology was in crisis, the regional elites with their common origin in the nomenklatura were transforming themselves from ideologically to consensually unified elites. They realized the necessity of cooperation in order to maintain and increase power but were now divided by ideas and interests, including those related to ethnic and linguistic issues. Language ideologies connect beliefs about languages and their place in society. Language practices reproduce ideologies, hierarchizing languages and normalizing this hierarchization. The titular and Russian discourses on these issues diverged in terms of problem identification, envisaged policy goals and proposed solutions (see Zamyatin 2018b).

Titular intellectuals explained that the low prestige of titular languages and their narrowed use in the public sphere caused language shift and 
believed that this was a result of deliberate discriminatory Soviet policy. They felt psychologically insecure, used the rhetoric of victimization and doubted the values of their languages and cultures. At the same time, they shared an ideology of linguistic pluralism and believed multilingualism to be a normal condition. Another ideology they shared without ever explicitly saying so aloud was linguistic nationalism with its belief in the central role of language for a nation. Both ideologies were rooted in the early Soviet ideology with its "equality of peoples and their languages", and the titular intellectuals now sought to return to these standards.

In the view of the titular activists, language revival as an aspect of national revival had to become the policy goal, with the intended effect of preventing and reversing the shift from the titular languages to Russian and, thus, changing the existing equilibrium. In Soviet times, many aspects of people's lives depended on the state and they were used to state paternalism. Due to the prevailing political culture, the activists believed that the state should act on the issue. This belief was also rooted in the rhetoric of entitlement and the claim of possession of the titular republic.

The local Russians also saw the condition of inter-ethnic relations as problematic and thus worthy of being raised on the governmental agenda. They pointed to ethnic tensions, conflicts and wars in some SSRs and also alleged discrimination of the Russian speakers, primarily in the Baltic republics. They also used the rhetoric of victimization and felt like a psychologically insecure majority because they had, unexpectedly for them, become minorities in the former SSRs and now also felt their majority position threatened in the former ASSRs and were prepared to discriminate reciprocally in order to protect their position. The ideology of the Russian elite segments was that of linguistic assimilation, and they envisaged monolingualism as the norm. Another implicit ideology was Russian linguistic nationalism, according to which Russian had to become the state language of Russia.

The implicit goal of the one-language-only policy was to sustain the shift from non-Russian languages to Russian, but it had to remain covert, because this idea contradicted the official Soviet discourse of internationalism. Assimilation and language shift were already ongoing practices. Thus, the explicit goal became the preservation of the status quo based on rhetoric about the need to prevent tensions and conflicts and to maintain inter-ethnic harmony. A further rationalization for monolingualism was based on the efficiency assumption, that the official use of two or more 
languages was impractical, and on the integration assumption, according to which Russian should be promoted because it would ensure a unified informational and cultural space in the country (Zamyatin 2014a).

Therefore, the elites shared the view that there were language-related problems that had to be addressed. The ideological tensions in republics were between pluralist and assimilationist discourses. But there was also a level of consensus, because both visions shared the ideology of linguistic nationalism and, thus, although for different reasons, also shared the view that the idea of state languages could be an appropriate solution. Another point of consensus was the idea about the equality of languages. Equality was perceived in the public discourse as the just way to solve the inter-ethnic tensions. The equality idea in conjunction with linguistic nationalism had such an effect that most people supported the official designation of two state languages. The conflict was over whether the official status of the titular languages implied only voluntary or also compulsory language use.

\subsubsection{Policy formulation}

The designation of state languages was a new approach not previously used in the Soviet times. Policymakers were compelled to act, but when the issue was discussed beyond symbolic recognition, the interests of elite segments diverged, and a public disagreement emerged about the meaning of the official designation of languages as the solution to the problems. Russian and titular elite segments referred to different standards to adapt this new approach: the Russian elites supported only the symbolic recognition the titular languages, whereas the titular elites insisted in addition on the practical use of these language as the official languages.

Three central questions emerged in public discussions that embodied policy alternatives: how many state languages there should be, whether they should be compulsory for study in all school of a republic and whether all inhabitants of a republic must know them. The solution to the first question came earlier "from above", and all republics except Karelia addressed the issue in their sovereignty declarations (for a discussion of the options, see Zamyatin 2013a: 126-139). In Karelia, the problems mounted, starting with the very basic issue that due to the lack of a standardized written form, the Karelian writers themselves were against the official designation of Karelian, as they could not agree on which variety should be chosen and perceived Finnish as a language with a higher prestige for that role (Zamyatin 2013a: 139-141). 
Most ASSRs first declared the official status of their state languages in their sovereignty declarations in autumn 1990 without having yet passed language laws, which amounted to symbolic recognition. Although the public was against soveregnization, it did not have a say, because the sovereignty declarations were drafted in parliamentarian commissions and adopted in parliaments with overwhelming majorities (see Zamyatin 2013a: 137-138). National organizations prepared their own drafts that were rejected, for example, in Komi. The general atmosphere of the processes of disintegration of the USSR made possible the sovereignization of these ASSRs as well. It was explicitly stated in the sovereignty declarations of some republics, e.g. Tatarstan, Komi and Mari, that the titular language and Russian as two state languages would function on equal footing (Zamyatin 2015: 297).

Titular pressure groups wanted to designate the titular languages with an official status not only because the symbolic recognition would increase the prestige of the language but also because it would enable their designation as compulsory as the mechanism for their expansion in the public sphere. Some politicians of titular nationality insisted that the titular languages should become the sole state languages of the republics, because in their opinion the co-official status of Russian would prevent or at least complicate the compulsory use of titular languages. However, this view was considered radical even by the titular elites themselves, most of whom could not imagine such a situation. For example, in the early 1990s, the chair of the national organization Udmurt Kenesh was himself against the introduction of Udmurt as the medium of instruction, because "it was not needed". Furthermore, there was a split in the national movements because a significant portion of the titular elites were themselves Russian speakers and often did not support the compulsoriness of the titular languages. As a result, the national organization in Tatarstan also supported the two-state-language solution (Zamyatin 2013a: 134-136).

The titular groups were to be the target community of the revivalist policy. Yet, the compulsoriness also had broad effects and directly touched upon the language behaviour of ethnic Russians and Russian speakers in the republics. They did not know or use the titular languages and their prevailing attitude towards them was that they had a low prestige and were not useful. Thus, the regional Russian elite segments were strongly predisposed against the compulsoriness of the titular languages. Furthermore, they suspected that the revivalist rhetoric was just a pretext while 
the actual goal of titular elites was to use the language requirement of firstrank officials to ensure preferential access of their representatives to power. At the same time, the prevailing discourse of "inter-ethnic accord" also restricted them from expressing their negative attitudes publicly so as not to undermine the existing level of consensus. Instead, the Russian politicians preferred not to voice their ideology explicitly but thumbed their noses behind the back of the proponents of compulsoriness of the titular languages.

As the aspirations contradicted one another, a compromise was needed. There was a need to reconcile and balance the conflicting interests of elite segments advocating for their ethnic groups. This compromise became possible, inter alia, because of the common origin of the elite segments in the nomenklatura. The position of the first figure on the issue and the leadership style, conflictual or consensual, was crucial. Furthermore, there was a joint interest among regional elites in increasing the republic's self-governance vis-à-vis the center (Zamyatin 2013a: 151-153).

The scope of the compromise regarding the second and third questions about compulsoriness was set in the RSFSR language law of 1991. The law introduced Russian as the state language of the whole country and permitted the compulsoriness of titular languages in certain domains, including education and at work. Therefore, the introduction of some elements of the compulsoriness depended on the political situation in each individual republic. In the early 1990s, there were still no agencies of the republics on nationalities affairs that were generally tasked with developing policy proposals. Language laws were drafted by regional parliamentarians or officials, as in Tatarstan, Komi and Mari El. By the mid-199os, ministries or state committees on nationalities affairs were created everywhere and began drafting the laws in those republics that still lacked them: Mordovia, Udmurtia and Karelia. Sometimes, law drafts were prepared by national organizations or research institutes (Zamyatin 2014b).

\subsubsection{Policy adoption}

Therefore, policy adoption consisted of not one but three steps: symbolic designation in the sovereignty declarations, formal designation in the constitution and legal designation in languages laws (see Zamyatin 2014a: 97-103). By form, symbolic designation actually did not amount to policy adoption because the sovereignty declarations were policy documents 
that expressed intention rather than action (see Zamyatin 2013a). By content, however, the policy option of the designation of the co-official state languages of republics remained the same as it had already been in the declarations.

The constitutional designation amounted to policy adoption, although it resolved only the most general issues: those about the co-official status and, in some republics, about language requirements of presidential candidates. The constitutions were adopted in the period between 1992 and 1995 in constitutional assemblies, which meant that the people were once again to a large extent sidelined from the discussion (for a detailed discussion on the adoption of the constitutions, see Zamyatin 2013b). Yet, according to the data of the 1993-1994 public opinion surveys, by that time, the co-official status of the languages reflected the prevailing public attitudes. This option was supported primarily by the titular groups but also by a sufficiently large share of the Russian-speakers to have overall majority support not only in the Finno-Ugric republics but also in Tatarstan (see subsection 4.3.3 below). The constitutions of the republics formalized their upgrade in political status to that of constituent republics of Russia with their own constitutions and state languages as symbols of their national statehood.

Tatarstan was the first to pass its constitution in 1992, before the Russian constitution of 1993 and the designation of Tatar and Russian as equal-in-rights state languages. The 1994 constitution of the Komi Republic designated Komi and Russian as the republic's state languages. The 1994 constitution of the Udmurt Republic designated Russian and Udmurt as its state languages. The 1995 constitution of Mari El designated two varieties of Mari (Hill, Meadow) and Russian as its state languages. The 1995 constitution of Mordovia designated Russian and two Mordvin languages (Moksha and Erzia) as its state languages. The Republic of Karelia did not designate its state languages at the time and designated only Russian in its 2001 constitutional amendment (see Zamyatin 2013b).

Most issues were left for legal designation in language laws. In public debate, the rhetoric of "language revival" was widespread but the policy goal was formulated and adopted in the laws as a more moderate "maintenance and development of languages", which implied the process but not necessarily the result (for a detailed discussion on the adoption of the constitutions, see Zamyatin 2013c). This became not an absolute goal but one balanced by the goal of maintaining the position of Russian as "the language of inter-ethnic communication" (literally, "inter-nationality 
communication") and enabling its further spread. In the next section, I will explore the specification in legislation of only the first goal.

\section{Policy inputs and outputs}

\section{I. Evaluation of policy institutionalization and implementation}

Legislators typically define policy inputs by not only formulating the goal of the language spread but also providing an itemized list of instituted elements of domains through the adoption of language laws and the allocation of budgetary funds, which I refer to as institutionalization. Accordingly, the indicators for measuring policy inputs are the share of instituted provisions and the amount of allocated funds. Executive authorities should then act as policy implementers and are responsible for producing policy outputs. Thus, the indicators for measuring policy outputs are of two types, the first depicting the share of institutionalized elements where the use of titular languages was actually introduced and the second depicting the share of measures that were actually implemented under executive programs, as sets of rules, routines and resources, or through everyday activities of executive agencies. Focusing on studying the relative shares makes it possible to see beyond the absolute numbers typical of official reporting.

The gap between policy goals and implementation is also typical for other countries and is well-studied (see Hill \& Hupe 2002). A specific feature of the situation in Russia was that it was the co-official status of languages that predetermined the problems of implementation. The republics' authorities took on the formal commitment to promote the titular languages but instituted only few obligations to actually use them. In order to reach a compromise, the revivalist goal was too broadly formulated and had to be pursued under the conditions of official bilingualism, when Russian was already used in all domains. Furthermore, the 1990 s revivalist projects were pursued mostly as a top-down policy narrow in scope because they mainly sought to increase language use within the elements of domains where titular languages already functioned and their expansion to new elements of domains was generally not planned. Thus, the patterns of covered elements of domains were also a Soviet legacy, and in post-Soviet times, there was no expansion of the titular languages to new domains, with some exceptions, notably information technology (see Zamyatin $2014 \mathrm{~b}$ and Table 7 in the next section). 
In Russia's republics, the policy institutionalization through language laws was done in vague terms and contained such contradicting ideas as the proclaimed equality of languages and the hierarchy of language statuses (see Zamyatin 2015). This shifted the task of filling in the details to the executive agencies to be created. In the early 199os, the regional ministries were typically assigned a non-itemized budget line with the proxy of developing governmental executive programs (especially those in the first stage, see Zamyatin 2014c). In other words, implementers enjoyed a discretion on implementation matters, in particular in allocating funds to concrete measures. This was the case partly because the institutionalization of the official language status in laws and implementation were disconnected, as the structure of laws and executive programs did not match (Zamyatin 2014c). In my earlier study, I demonstrated that the broad discretion given to the government officials over the issues of implementation coupled with the officials' attitudes of "benign neglect" and lack of commitment to the task was a significant reason for the poor implementation or non-implementation of policy measures (Zamyatin 2014a: 104-108).

However, there were also technical obstacles that led to poor implementation. The definition of societal problems in relative rather than absolute terms determines the limitation of policy in affecting conditions (Dye 2013: 78). The institutionalization was often not specified into objectives and, thus, was difficult to operationalize for the purpose of implementation and evaluation. No specific targets or measurement units were set in the fields of activities such as the number and nature of public services to be made available. Another problem was that the agencies were in charge of both implementation and the evaluation of implementation. As a result, their reports tended to consist of lists of activities that focused on progress rather than on shortcomings. Further, a crucial weakness was the lack of consideration for the role of titular community organizations, although in practice pressure groups often had much leverage on the agencies, for example, through participation in advisory bodies or other forms of consultations or as contractors for the activities undertaken in order to implement the policy measures (for a similar situation, see De Korne 2012).

How is it possible to evaluate policy institutionalization and implementation? Based on the policy analysis approach, François Grin (2003) developed a model of policy evaluation in the context of the European Charter on Regional or Minority Languages. He pointed out that "the desired outcomes of the policy measures to be adopted under the Charter ought to be 
the continued vitality of those languages, meaning that they ought to be known - and used". To specify the content of the vitality, Grin used Joshua Fishman's graded intergenerational disruption scale (GIDS), which contains eight stages on the scale of "threatenedness" of languages, with stages 8 to 5 amounting to minority language use in private and stages 4 to 1 in the public sphere (Fishman 1991). Grin further noted that one way to define the desired outcome is a general movement towards stage 1 of the GIDS. He sums up that the improvement of the position of languages on the GIDS scale should achieve some minimum results of "restoring and maintaining self-priming mechanisms of language reproduction", which coincides with stage 5 (see Grin 2003: 40-42).

In Russia, the titular Finno-Ugric languages also found their way into the public sphere as officially recognized state languages of republics (except in Karelia). Moreover, the revivalist goal itself was to be achieved through the expansion of the use of the languages in official contexts through its institutionalization in law. Tatarstan and Komi started to pursue revivalist policies quite assertively in terms of inputs, passing their language laws already in 1992. Mari El was also assertive and passed a strong law in 1995, but the policy underwent to an abrupt change at the turn of the millennium. In contrast, Mordovia and Udmurtia were slow in launching the policies through the adoption of their language laws in 1998 and 2001, respectively (see Zamyatin 2014b). Therefore, to evaluate whether the policy achieved its goal is to study the expansion of languages into domains of the public sphere.

Based on the GIDS, I developed a model for classifying language use in the public sphere depending on public institutions. I distinguish language use (1) by the bodies of state authorities, (2) in the work environment of public institutions, (3) in state-funded mass media and cultural institutions (4) in public schools. Further, depending on its functions, I distinguish language use (1) in the office, (2) in communication with citizens, and (3) in the provision of public services (see Zamyatin 2014a). Essentially, the republics' language laws prescribed the use of the titular languages across some elements of three domains of the public sphere: languages in the bodies of state authorities, official mass media and education. Their use in the work environment was not instituted, but sometimes some implementation measures were taken.

In other words, the titular languages were granted only "limited officiality" both in the scope and extent of institutionalization, as Russian already 
performed all functions. For example, courts and law-enforcement agencies fall under the federal competence and are thus monolingual Russian, with the exception of the right to translation. Thus, the scope of the use titular languages was restricted to certain regional authorities (see Zamyatin 2015). In my study on institutionalization, I demonstrated that the use of titular languages in official contexts, in addition to Russian, was either (1) not instituted in the language laws, (2) instituted but never implemented or (3) instituted and at least partially implemented. In the second case, one can only speak about indirect effects on language prestige. Thus, it is only in the third case, when legal provisions were at least partially implemented, that it is possible to evaluate the extent to which policy outputs were achieved (Zamyatin 2014b).

According to François Grin's policy-to-outcome path, implementation measures are taken to create of the conditions for language use: the capacity, opportunity and desire to use the minority language (Grin 2003: 43-48). As a result of cross-fertilization, measures of status planning, acquisition planning or prestige planning typically affect different aspects of language behaviour simultaneously, but the different types of language planning mainly affect one condition for language use. In Russia's republics, at the core of status planning was the creation of opportunities to use the languages, in particular attempts to spread the use of the titular languages in the bodies of state authorities. Acquisition planning and capacity development were central in the sphere of education. Mass media was illustrative of the desire to use the languages. In the next section, I will explore policy the volumes of inputs and outputs directed at creating the conditions for language use accordingly in each of four domains.

\subsection{Creation of conditions in the domains of language use}

\subsection{Authorities' offices and the work environment: opportunity}

Status planning included the designation of the titular languages with an official status of state languages of republics and relied on their compulsory use as the means of their promotion. The official recognition has not resulted in the introduction of titular languages as the working languages of state authorities. The use of titular language in parliamentary debates was permitted in such activities as drafting laws and discussions, including work in committees, the publication of laws as well as in official 
documentation and correspondence. The republics typically instituted the right to speak in both languages at parliamentary sessions. However, the prevailing attitude was that the titular languages were considered insufficiently linguistically developed, although they had literary traditions and standardized written forms, with the exception of Karelian, which acquired a written form in 1989. To address the latter problem, language boards were created in every republic with the mission of corpus planning.

Compulsory knowledge of the official language by (a candidate for the post of) the head of a state or territory is an important element of language status. This requirement can have dual justification within the language status: as a part of the working language of the state authorities and as a language preference. Language preferences and the requirement to know both state languages were justified in the republics by the multinational character of their statehood. Among the Finno-Ugric republics, the requirement of knowledge of both state languages of the republic for the head of state were introduced only in Mari El. However, when an incumbent head attempted to apply the provision, this provoked a conflict, so the provision was never enforced (Zamyatin 2013b).

Language requirements for officials and civil servants were justified as the way to ensure the right of citizens to address authorities in the state languages. Despite the plans, almost nowhere were language requirements instituted and also implemented. In Mari El, in addition to the general provision of language requirements, there was a provision on language requirements from heads and employees of educational institutions, while language requirements for some professions did not pass in the language law. In Tatarstan and in Karelia, financial bonuses for the knowledge and use of languages in professional activities were introduced (see Zamyatin 2014b). Some official data is available on measures for the promotion of titular languages in the work environment. For example, annual language courses for public officials and citizens were organized in Komi and Udmurtia. In Komi, language requirements for some professions did pass into the original law, but the list of professions was never approved (see Zamyatin 2013c: 137). A total of 150 public officials attended such courses during the six years between 2006 and 2012 (Gabusheva 2013). All in all, the attempts to expand the use of titular languages did not reach the objectives of creating new opportunities for language use in official contexts. 


\subsubsection{Communications with citizens, public services: opportunity}

Language laws not only regulated language use by authorities and their officials but also in the authorities' communication with citizens and in the provision of public services. In my study of these two latter contexts, I found that the elements of domains in which titular languages had to function as the medium of the interaction of authorities with citizens were partly instituted. In some republics, the right to choose the language of communication in requests from authorities and the obligation of authorities to respond were instituted. Both state languages could be used in the text of documents (forms, seals, stamps or signboards with the names of authorities), as well as in official documents verifying identity and other information (passports; birth, marriage and death certificates; diplomas; military cards; etc.). In addition, the right to have traditional personal names, the right to have access to information and the obligation of authorities to provide such information were included in the Mari El language law.

The elements of domains of public services were also partly but somewhat better instituted. The language laws allow, but do not require, both state languages to be used in consumer services and commercial activities, industry, agriculture, communications, transport, power engineering, marking of goods and instructions for goods, labels, standards, nomenclature, texts of official announcements, visual and audible advertisements and other information, timetables, audible and visual announcements in airports, railway stations, river ports, bus stations, road signs and geographical names. The institutionalization of these elements did not mean that they were to be used automatically, and civic initiative was often needed to launch their implementation. Further, in the early 2000 s and the early 2010s, the number of instituted provisions decreased (see Zamyatin 2013c). If one compares the instituted and at least partly implemented elements across the republics in the 200os, the following picture appears (see Table 7 on the following page).

For the sake of simplicity, I have presented in Table 7 the data not on all but only on the key elements of four domains (for the full list, see Zamyatin 2014b). This selection makes their presentation incomplete but visualizes the data well and allows for a general comparison of the policies. To complicate the picture, the authorities used the legal language of qualifications like "can", "if possible", or "according to legislation" to weaken legal provisions especially in Karelia and Udmurtia, which suggests that they 


\begin{tabular}{|c|c|c|c|c|c|}
\hline Republic & Komi & Mari El & Mordovia & Udmurtia & Karelia \\
\hline $\begin{array}{l}\text { 1. Requirement for } \\
\text { top officials }\end{array}$ & $\mathrm{O}$ & 1 & o & o & $\mathrm{o}$ \\
\hline $\begin{array}{l}\text { 1a. Rights to speak } \\
\text { at sessions }\end{array}$ & 1 & 1 & 1 & 1 & 1 \\
\hline $\begin{array}{l}\text { 1a. Languages of } \\
\text { draft laws }\end{array}$ & O & o & o & $\mathrm{o}$ & $\mathrm{o}$ \\
\hline $\begin{array}{l}\text { 1a. Languages of } \\
\text { discussions }\end{array}$ & $\mathrm{O}$ & o & $\mathrm{o}$ & $\mathrm{O}$ & $\mathrm{o}$ \\
\hline $\begin{array}{l}\text { 1a. Languages of } \\
\text { law publication }\end{array}$ & $1 / 1$ & 1 & 1 & 1 & 1 \\
\hline $\begin{array}{l}\text { 1b. Texts of docu- } \\
\text { ments and } \\
\text { signboards }\end{array}$ & $1 / 1$ & $1 / 1$ & $1 / 1$ & $1 / 1$ & $1 / 1$ \\
\hline $\begin{array}{l}\text { 1b. Audio-visual } \\
\text { information }\end{array}$ & $1 / 1$ & $1 / 1$ & $1 / 1$ & $1 / 1$ & $1 / 1$ \\
\hline $\begin{array}{l}\text { 1c. Right of citizens } \\
\text { to request }\end{array}$ & 1 & $1 / 1$ & 1 & 1 & $\mathrm{o}$ \\
\hline $\begin{array}{l}\text { 1c. Obligation } \\
\text { to respond }\end{array}$ & 1 & 1 & 1 & 1 & $\mathrm{o}$ \\
\hline $\begin{array}{l}\text { 2. Language } \\
\text { requirements }\end{array}$ & $\mathrm{O}$ & 1 & o & $\mathrm{o}$ & 1 \\
\hline $\begin{array}{l}\text { 3. Languages in } \\
\text { mass media }\end{array}$ & $1 / 1$ & $1 / 1$ & $1 / 1$ & $1 / 1$ & $1 / 1$ \\
\hline $\begin{array}{l}\text { 4a. State languages } \\
\text { for all pupils }\end{array}$ & $1 / 1$ & 1 & $1 / 1$ & $\mathrm{o}$ & $\mathrm{o}$ \\
\hline $\begin{array}{l}\text { 4b. Native language } \\
\text { of instruction }\end{array}$ & $\mathrm{O}$ & 1 & $1 / 1$ & $\mathrm{o}$ & $\mathrm{o}$ \\
\hline $\begin{array}{l}\text { 4c. Native language } \\
\text { as a subject }\end{array}$ & $1 / 1$ & $1 / 1$ & $1 / 1$ & $1 / 1$ & $1 / 1$ \\
\hline $\begin{array}{l}\text { Instituted, not used / } \\
\text { partly used elements }\end{array}$ & $9 / 6$ & $11 / 7$ & $10 / 6$ & $8 / 4$ & $7 / 4$ \\
\hline
\end{tabular}

$\mathrm{o}-$ not instituted

1 - instituted, not used or implemented

/1 - instituted, partly used or implemented

Table 7: Institutionalization of selected elements of the official status of the titular Finno-Ugric languages in language laws (adapted from Zamyatin 2014b) 
actually lacked the intention to implement the respective provisions. Notably, in all republics, almost exclusively those elements were instituted that increase the visibility of the languages: texts of documents and signboard were to be translated and audio-visual information provided. For example, the distribution of public information in the state languages of the republic was regulated in Mari El. I have suggested that this was due to the circumstance that the titular languages were used in the official contexts mostly in their symbolic function, and the majority made concession in this part but not regarding the practical function. This also indicated the inability of policymakers to change the existing interactional order (see Zamyatin 2014a).

It is not easy to quantitatively overview the implementation of language provisions in communication with citizens and public services. The units of measurement could include the number, frequency and duration of opportunities to use the language in dealings with authorities (see Grin 2003: 100). However, the official data on language use in public services is scarce, and only circumstantial evidence is accessible. For example, the installation of bilingual signposts is the only obligation under federal legislation. The installation of bilingual signposts or the translation of documents is a one-time event, which makes it possible to count. The agencies typically provide numerical information on the implementation of these two activities, but no quantitative studies have been conducted. There have been no studies on language landscapes in the Finno-Ugric republics like those conducted in Tatarstan (see Gabdrahmanova et al. 2016). The Komi Republic was by far the first among the Finno-Ugric republics in instituting and implementing the use of the Komi language in official contexts. For example, the republic's laws were translated into that language. But even in this republic, the installation of bilingual signposts was not fully completed, except in the towns of Syktyvkar and Ukhta (Gabusheva 2013). In Udmurtia, officials reported that some laws were also translated and provided the information on the absolute number of the translation of the names of public and commercial legal entities (see Implementation Report 2014). In contrast, the Republic of Tatarstan instituted the use of Tatar along Russian in all the elements listed in Table 7 (see Iskhakova 2002). 


\subsubsection{Education: capacity}

The main focus in language education is on the creation of the capacity to speak a language. By the end of the Soviet era, most national schools in the Finno-Ugric republics were situated in the countryside and had Russian as the language of instruction, while the native language was taught as a subject only. The objective of the revivalist project in education was to increase access to native language learning as a subject and ultimately to provide it to all titular pupils, including in urban areas. Native language of instruction was also to be expanded where it existed, that is, in rural schools in Mari El and Mordovia. The objective to introduce the native language of instruction was not pursued, although it was discussed in the early 1990s, for example, in the Komi Republic. The teaching of titular languages as state languages of the republic as a compulsory subject to all pupils irrespective of their ethnicity was introduced at different times in Komi, Mari El and Mordovia. While units of measurement were defined to enable quantitative evaluation, no separate objective of skills development was set to focus on increasing the level of competence, and qualitative evaluation remains problematic.

In a separate study, I systematically evaluated the implementation of language policy in education with the help of both qualitative and quantitative methods based on the official data (for the data and methodology, see Zamyatin 2012b, 2012C; see also Zamyatin 2016 for the evaluation in relation to the Charter standards). On the policy input side, there are resources to invest, such as the numbers of hours in the curriculum, textbooks and supply materials, schools and trained teachers. I took access to native language learning in one of the three modes, the native language of instruction, as a subject of native language or a subject of state language, as an indicator of policy outputs and diachronically compared it across the republics. The combined data illustrate the processes that were ongoing in language education in the Finno-Ugric republics during the two postSoviet decades (see Table 8).

The data demonstrate that the access to native language learning in the Finno-Ugric republics was only partially provided. In general, probably up to a quarter of titular schoolchildren studied their native language in any form in Karelia, up to half in Komi, Mordovia and Udmurtia, and up to three quarters in Mari El. Karelia and Mari El achieved more in terms of outputs. In Karelia, the access to native language learning either as a native 
Evaluating language revival policies of Russia's Finno-Ugric republics

\begin{tabular}{|l|r|r|r|r|r|r|}
\hline Republic & \multicolumn{1}{c|}{ Komi } & Mari El & Mordovia & Udmurtia & Karelia & Tatarstan \\
\hline Year & $1990 / 1991$ & $1990 / 1991$ & $1990 / 1991$ & $1989 / 1990$ & $1989 / 1990$ & $1990 / 1991$ \\
\hline Instruction & 0 & 8,706 & 4,719 & 0 & 0 & 65,074 \\
\hline Native lang. & 15,890 & 27,700 & 16,576 & 29,278 & 301 & 192,600 \\
\hline State lang. & 3,483 & - & - & - & - & $\mathrm{n} / \mathrm{a}$ \\
\hline Year & $1999 / 2000$ & $2000 / 2001$ & $1999 / 2000$ & $2000 / 2001$ & $2000 / 2001$ & $2000 / 2001$ \\
\hline Instruction & $\mathrm{o}$ & 6,316 & 3,597 & 0 & 0 & 150,632 \\
\hline Native lang. & 16,926 & 25,974 & 16,136 & 33,143 & 2149 & 313,750 \\
\hline State lang. & 21,224 & 46,559 & 3,191 & - & - & $99.1 \%$ \\
\hline Access & $\sim 52.1 \%$ & $81.9 \%$ & $\sim 41.7 \%$ & $41.2 \%$ & $17.6 \%$ & $99.6 \%$ \\
\hline Year & $2009 / 2010$ & $2009 / 2010$ & $2009 / 2010$ & $2008 / 2009$ & $2009 / 2010$ & $2010 / 2011$ \\
\hline Instruction & 0 & 273 & 1,689 & 0 & 0 & 85,516 \\
\hline Native lang. & 6,200 & 11,616 & 7,670 & 19,315 & 1,581 & 185,392 \\
\hline State lang. & 27,800 & 29,304 & 15,493 & - & - & $\sim 100 \%$ \\
\hline Ethnic share & $\sim 55.6 \%$ & $\sim 84.3 \%$ & $\sim 50.2 \%$ & $\sim 44.8 \%$ & $\sim 25 \%$ & $\sim 100 \%$ \\
\hline
\end{tabular}

Table 8: Number of students of titular nationality learning the titular languages in the Finno-Ugric Republics in three modes (as the language of instruction or as a subject of native language or state language) and share of students with access to native language learning in any of these forms (adapted from Zamyatin 2012b, 2012c)

or a state language increased from $3.4 \%$ in 1990 to $17.6 \%$ in 2000 and was about $25 \%$ in 2010. In Mari El, the access to native language learning was $55.2 \%$ in 1990 and remained relatively stable despite the policy change in 2001, when up to half of the Mari pupils had access, while by 2000 most of the rest had to learn Mari as the state language of the republic. Neither secondary professional nor higher education was available, except for training of native language teachers.

In contrast, the share of Tatar schoolchildren having native language of instruction increased from $12 \%$ in 1990 to $48 \%$ by 2000 , while the rest learned Tatar as a subject of native language. Exceptionally, some humanities courses in secondary professional and higher education were also provided in Tatar (2.5\% of all students). Until 2017, when compulsory teaching was abolished, practically all non-Tatar schoolchildren in Tatarstan had to learn Tatar as a subject of state language (Zamyatin 2012C, State Program of Tatarstan 2013). 
It is complicated to study language competence as a policy output, either quantitatively or qualitatively. One problem is that only about two thirds of those who start studying the native language in primary school continue to do so also in secondary school. Furthermore, an unintended consequence of the policy was that the introduction of the compulsory study of the state language actually negatively affected native language teaching, since the 2007 education reform changed the setting. The reform introduced the satisfaction of linguistic and ethnocultural demands of people as the criterion of language policy effectiveness (Zamyatin 2012a). Schools anticipated low parental demand and started to switch the language teaching from that of a subject of native language, which had to become voluntary, to that of the compulsory subject of state language. The problem is that far fewer hours are assigned to teaching in the latter mode and the teaching is of lower quality (see Zamyatin 2012b). In the future, the criterion of satisfying the linguistic demands would make it possible to study also the desire to learn the language, but due to the lack of systematic data, this is currently not possible.

After an increase in the 1990s, access to one's native language and the volume of teaching of the Finno-Ugric languages decreased in the 2000 s. The 2007 education reform has further worsened the position of the FinnoUgric languages in the education system. Until recently, the negative trend in this process of decrease was due to the closure of small rural schools in the campaign for "optimization of the education system". Since the reform, the number of schoolchildren learning their native language has been further decreasing as a result of the absence of the declared linguistic need expressed by parents or their preference for other subjects in the formation of the school curriculum (see Zamyatin 2012a). The existing quantity and quality of language teaching does not ensure the reproduction of language competence of a significant portion of schoolchildren of titular ethnic origin (see Zamyatin 2012b).

\subsubsection{Mass media: desire}

Demand for products in a language reveals the desire to use the language. The level of demand also indicates the effectiveness of measures directed at prestige planning but is difficult to study. Mass media is illustrative of the desire to use the language because people are free to order subscriptions. 
Since the Soviet times, books, journals and newspapers have been printed in the titular languages of the republics and TV and radio broadcasting have been arranged, because these were the channels of ideological indoctrination. With the introduction of the freedom of the press in the early 1990s, there has been an interesting interplay between supply organized by the republics' authorities and popular demand. Under the conditions of the drop in popular demand during the economic crisis of the 1990s, the objective was not to expand but only to sustain the level of supply. Policy outputs are influenced by many other variables besides popular demand, including economic and technological ones. However, one indirect way to study demand is to assess the trends in minority media in relation to the output in the Russian language, thus sidelining the effects of variables that influence all languages.

Therefore, when compared to the dynamics of printing in Russian, one can indirectly speak about regional policy outputs. In the republics, substantial funding was typically allocated in the executive programs for book-printing in the state languages of republics and other local languages. Publications for children and schoolbooks are in particular focus, along with their distribution to libraries and schools, including among diasporas. The republican budget finances periodicals, as well as the making of broadcasts and telecasts. In addition, the executive programs provide funding for dubbing and subtitles.

I observed the dynamics of the provision of media products in the titular languages of the Finno-Ugric republics during the two post-Soviet decades, comparing the trends based on the official data, which are for the whole of Russia. When the output in 1990 is taken as constant (100\%), the calculation shows the following trends in printing in the titular FinnoUgric languages (see Table 9 on the following page).

As can be seen from the data regarding books and brochures, the republics' authorities annually commissioned up to two dozen titles, with the average total editions amounting to tens of thousands in the Komi, Mari, Mordvin and Udmurt languages. For Karelian, both the numbers of titles (only a few) and average editions (some thousands) have been clearly smaller.

In 1991, only $3 \%$ of all books published in Russia were in non-Russian languages and in 1996 this share decreased to 2.3\%. Most of the non-Russian books were in Tatar and Bashkir, while the share of other non-Russian languages was about 20\% (Hudaverdian 1998). The data show that, over the 


\begin{tabular}{|c|c|c|c|c|c|c|}
\hline \multirow{3}{*}{ Russian } & \multicolumn{2}{|l|}{1990} & \multicolumn{2}{|l|}{2000} & \multicolumn{2}{|l|}{2010} \\
\hline & \multicolumn{6}{|c|}{ Issue of books and brochures in selected languages of the peoples of Russia (titles) } \\
\hline & 37,740 & $100 \%$ & 56,863 & $151 \%$ & 118,378 & $314 \%$ \\
\hline Tatar & 169 & $100 \%$ & 210 & $124 \%$ & 280 & $166 \%$ \\
\hline Karelian & 3 & $100 \%$ & 4 & $133 \%$ & 1 & $33 \%$ \\
\hline Komi & 29 & $100 \%$ & 24 & $83 \%$ & 35 & $121 \%$ \\
\hline Mari & 72 & $100 \%$ & 15 & $21 \%$ & 29 & $40 \%$ \\
\hline Mordvin & 35 & $100 \%$ & 11 & $31 \%$ & 30 & $86 \%$ \\
\hline Udmurt & 28 & $100 \%$ & 9 & $32 \%$ & 5 & $18 \%$ \\
\hline \multicolumn{7}{|c|}{ Editions of books and brochures in selected languages of the peoples of Russia (thousands) } \\
\hline Russian & $1,499,722$ & $100 \%$ & 445,041 & $30 \%$ & 641,659 & $43 \%$ \\
\hline Tatar & 3,436 & $100 \%$ & 411 & $12 \%$ & 1,776 & $52 \%$ \\
\hline Karelian & 11 & $100 \%$ & 6 & $55 \%$ & 0.3 & $3 \%$ \\
\hline Komi & 106 & $100 \%$ & 85 & $80 \%$ & 39 & $37 \%$ \\
\hline Mari & 301 & $100 \%$ & 16 & $5 \%$ & 33 & $11 \%$ \\
\hline Mordvin & 135 & $100 \%$ & 39 & $29 \%$ & 14 & $10 \%$ \\
\hline Udmurt & 149 & $100 \%$ & 7 & $4.7 \%$ & 11 & $7 \%$ \\
\hline \multicolumn{7}{|c|}{ Issue of newspapers in selected languages of the peoples of Russia (titles) } \\
\hline Russian & 4,488 & $100 \%$ & 5508 & $123 \%$ & 9,166 & $204 \%$ \\
\hline Tatar & 89 & $100 \%$ & 72 & $81 \%$ & 172 & $193 \%$ \\
\hline Karelian & o & & 3 & & 4 & \\
\hline Komi & 4 & $100 \%$ & 1 & $25 \%$ & 5 & $125 \%$ \\
\hline Mari & 16 & $100 \%$ & 11 & $69 \%$ & 15 & $94 \%$ \\
\hline Mordvin & 2 & $100 \%$ & 2 & $100 \%$ & 4 & $200 \%$ \\
\hline Udmurt & 18 & $100 \%$ & 7 & $39 \%$ & 10 & $56 \%$ \\
\hline \multicolumn{7}{|c|}{ Editions of newspapers in selected languages of the peoples of Russia (thousands) } \\
\hline Russian & $37,391,289$ & $100 \%$ & $6,973,018$ & $19 \%$ & $9,391,206$ & $25 \%$ \\
\hline Tatar & 192,233 & $100 \%$ & 60,767 & $32 \%$ & 51,835 & $27 \%$ \\
\hline Karelian & $\mathrm{o}$ & & 275 & & 54 & \\
\hline Komi & 2,870 & $100 \%$ & 315 & $11 \%$ & 1,149 & $40 \%$ \\
\hline Mari & 9,946 & $100 \%$ & 3,573 & $36 \%$ & 1,485 & $15 \%$ \\
\hline Mordvin & 2,106 & $100 \%$ & 686 & $33 \%$ & 333 & $16 \%$ \\
\hline Udmurt & 9,720 & $100 \%$ & 3,091 & $32 \%$ & 1,321 & $14 \%$ \\
\hline
\end{tabular}


Table 9 (on the left hand page): Average annual numbers of titles of books, brochures, periodicals and newspapers published in Russian and the titular Finno-Ugric languages (titles) and the dynamics in relation to the output in 1990 (\%) (the data on Mari and Mordvin for both languages/varieties)

Sources: data of Goskomstat Rossii, cited for 1990 and 2000 from the Russian Statistical Yearbook 2009, cited in Yazykovoe raznoobrazie 2010; data for 2010 from Finnougorskii mir 2012.

two post-Soviet decades, the number of books published in Russian tripled, while the numbers of books published in the Finno-Ugric languages decreased, although remaining relatively stable, which is probably the result of efforts on the part of the republics' authorities. At the same time, while the book editions in Russian were restored to half of the 1990 level, the book editions in the republics significantly dropped, which probably demonstrates diminished demand.

As for printed mass media, within the approximately two decades, the number of journals and newspapers in Russian almost doubled, and the numbers of journals and newspapers published in the Finno-Ugric languages remained relatively stable, which is again probably the result of efforts of the republics' authorities. The republics' policy was to intervene in order to support mass media. For example, in Udmurtia, the regional legislature and the government became co-founders of three official newspapers and the State Television and Radio Broadcasting Company Udmurtia in 1995.

In every republic, there is at least one official newspaper and one journal in the titular language, but the volumes of their circulation have been low and subscription from outside of the respective republics is virtually impossible. According to the official data, two to three newspapers have been published throughout the post-Soviet period in the Karelian, Komi and Mordvin languages; for Mari and Udmurt, the number of newspapers is higher. A rapid rise in the number of periodicals and newspapers during the perestroika times was followed by a dramatic decrease. For example, the number of newspapers dropped from eighteen in Udmurt and sixteen in Mari in 1990 to seven and eleven, respectively, by 2000, and somewhat recovered to ten and fifteen in 2008. About two to four journals with an average circulation of tens of thousands have appeared in the Komi, Mari, Mordvin and Udmurt languages (see Table 9). 
At the same time, circulations dropped by many times and never recovered. Editions of journals and newspapers in Russian were restored up to a third and a quarter, respectively, of the 1990 level. The drop in editions of journals in the republics was higher, which is probably another indicator of diminished demand, especially among blue-collar workers. In the case of newspapers, the decrease in editions in the Finno-Ugric languages is comparable to that of those written in Russian. The demand for newspapers was relatively stable probably because the readers reside mostly in the countryside with no other comparable sources of information available.

Since the Soviet times, there has been regional TV and radio broadcasting in local languages. There was an idea to provide broadcasting in minority languages on federal channels, but it was never implemented, and federal channels are exclusively in Russian. In the post-Soviet period, state-owned TV and radio broadcasting channels in the republics have continued to offer some broadcasts in the titular languages, usually about an hour per week on television and several hours per week on radio. Private commercial enterprises rarely issue cultural products in minority languages, as it is considered unprofitable due to the low demand, and these products often are considered to be of poorer quality than those available in Russian.

In the new era, the broadcasting hours of regional TV and radio companies have also been decreasing rapidly. In 2005, all regional TV and radio companies were resubordinated to the All-Russian State TV and Radio Company. This led to a further decrease in the number of broadcasting hours in minority languages on the waves of the Russian official state radio. Still, in Udmurtia, for example, in 2007 , the volume of broadcasting in the Udmurt language on TV was ten hours and on the radio seventeen hours per week (Semionov 2008). However, the quality of news in titular the languages in periodicals as well as in broadcasting is not sufficient, inter alia, because subsidies make them less competitive. As a rule, news in Russian offers more information and is of higher quality (Etnosotsiologicheskoe issledovanie 2000).

An extensive study has been carried out on the position of Finno-Ugric languages on the Internet. According to the data, there has only been a little progress in twenty years' time and not all languages have all the necessary language resources and tools available in order to enable their use as languages of the information environment. Only Komi and Udmurt have language corpora, while Komi, Mari and Udmurt have spell-checkers, 
purposeful corpora and native character sets. The websites of the respective republics' authorities are translated into Komi and partially into Mari, Udmurt and the Mordvin languages (Fedina 2016).

\subsubsection{Diverging inputs and outputs across the republics}

In this section, I demonstrated that there was a mismatch between policy inputs and outputs in terms of instituted and at least partially implemented provisions. Another mismatch was observed between the measures only "formally implemented" by box-ticking and those also actually implemented (see Zamyatin 2014c: 229). Third, the amount of inputs and outputs in the republics have diverged. In the early 1990s, despite the inevitable delay in their launch due to bureaucratic inertia, policies were relatively assertive in terms of the institutionalization of the compulsory use of titular languages, especially in Mari El and Komi, but this was not reflected in equal inputs, if measured in the passing of executive programs and the amount of funds assigned to them as indicators of policy input. This was partly due to the economic crisis of the early 1990 s and the 1998 default. In the 200os, the funding became more stable but political will to pursue revivalist projects decreased due to the incremental regime change in the country.

Since 2000, the amount of funds assigned for policy implementation in Mari El was reduced to a negligible amount due to the political situation. In the other republics, the amount of funds was comparable, including Karelia. That said, the target group in Karelia was many times smaller compared to the other titular groups and, thus, the input per individual in the target group was more substantial. Inputs in individual republics seem to have correlated with outputs (see Table 1, Zamyatin 2014c: 252-253). Insufficient inputs also resulted in inadequate outputs, which I measured by figuring out the trends in the evolution of such indicators as access to native language learning, volumes of printed materials and others. Outputs were not up to the task of creating the conditions for language use. In contrast, in Tatarstan, long-term planning, continuity in policy implementation and adequate allocation of resources led to the achievement of significant progress in outputs in all domains (see Zamyatin 2014c). 


\section{Policy outcomes}

\section{I. Evaluation of policy outcomes}

How can one evaluate whether the effects of policy outputs matched the desired outcomes? Typically, it is much more difficult to conduct a quantitative evaluation of policy outcomes because of the scarcity of data. According to Grin, the best solution in this situation is to carry out surveys of language competence and language use, or at least on language attitudes in the population, at regular intervals. Alternatively, it is also possible to collect statistical data on a range of language skills and patterns of language use separately, for example about enrolment in language learning, television audiences or sales of printed matters. The analysis of the evolution in indicators should then establish whether there is the link between policy measures and outcomes. This method produces only correlations that have to be substantiated in order to separate the effects specific to policy, that is, ones that would not have taken place without policy. A policy can then be evaluated as effective in comparison to any alternative policy, if policy measures incur actual positive changes through the creation of the conditions for language use (Grin 2003: 102-103).

In Russia's ethnic republics, the policy formation took a similar scenario when the goal became the expansion of the use of titular languages in the public sphere. The narrow policy scope and relatively low-intensive policy input and outputs into the sociolinguistic situations makes it problematic to discern policy effects from the effects of social, economic and other factors. For example, how much were the closure of newspapers and the drop in their circulations due to economic competition and how much due to diminished support? It is hardly feasible to produce a projected trend line. The comparison of potential and actual outcomes is prevented by the fact that there are too many variables. Furthermore, the lack of consistent data presents a methodological problem. The task of conducting one's own surveys is unrealistic because of the scale required to trace trends for entire groups. Alternative sources are official statistics and surveys commissioned by regional agencies. Statistical data are typically available but are not especially useful because they do not allow for distinguishing effects of the social structure and policy effects under the conditions of insignificant input. It would be more relevant to collect semi-official survey data on language knowledge, language use 
and language attitudes among the titular groups, but obtaining such data is also more problematic.

Thus, the next difficulty is the significantly limited accessibility of data under the current authoritarian regime. At the central level, the data concerning the monitoring of inter-ethnic relations were made secret after the creation of a new federal agency for nationalities affairs headed by a former secret service operative. At the regional level, the approach of executive agencies to report on policy outputs and outcomes in absolute numbers focusing on progress might be a deliberate choice in order to avoid publicity. For example, the recent reporting on the ongoing program on inter-ethnic relations in Udmurtia uses a sophisticated system of quantitative indicators that enable measuring the dynamics in the citizens' opinions about the state of inter-ethnic relations but only mentions the indicators in absolute numbers on books and their editions in Udmurt ("o" books published for the period, see Implementation Report 2014). Thus, official reports might deliberately conceal policy outcomes and prevent the use of post-program comparison. At the same time, one reason for a bias toward positive results in reporting on government-sponsored research is that the establishment of language revival programs had a primarily symbolic value. Even if the programs did not actually change the conditions of the target groups very much, their effect was to make the titular group feel that the government "cares" about their concerns (see Dye 2013: 75).

Further, not only authorities but also research institutes might provide biased information intended to misrepresent the situation for political reasons. A relevant ministry and a research institute might produce diverging data, because in the first, the supporters of the language revival project might prevail, while in the second, the proponents of Russian nationbuilding, who would be critical of the project, would be predominant. For example, the 2007 data of the Komi ministry of nationalities affairs on language use and attitudes are probably overestimated (Long-term Program 2009) but the 2004 data of the Institute of Language, Literature and History at the Komi Scientific Center of the Russian Academy of Sciences, seem to be underestimated (Opros 2004) when compared to similar data from the other republics. It must also be noted that in the background, there was a conflict about the compulsory teaching of Komi to all pupils (see Zamyatin 2013c). The research institutes are dependent on the academy and not only monitor the situation but also serve to implement the central policy of promoting the all-Russian identity in the regions. 
Thus, the survey data should be taken with a degree of mistrust, not only because there might be problems in consistency of data, such as representativeness, but also because there could be a hidden agenda aiming to conceal the actual policy impact. Furthermore, consistency in the data does not guarantee its adequacy, because in addition to respondents possibly falsifying their preferences, domestic researchers may also be politically biased or employ self-censorship because inter-ethnic relations are perceived under an authoritarian regime to be a sensitive area. Finally, it is difficult to detect the evolution in indicators because they have rarely been consistently surveyed over time periods.

What makes the study of impact simpler is that the alternative policy in the given case would be a mere symbolic policy and the absence of the instrumental policy (see subsection 2.3.3 above; Zamyatin 2018a). The continued situation of the provision of a low-level supply of services in titular languages due to inertia since the Soviet times implied the actual promotion of Russian based on the laissez-faire principle. It is a less complex task to search for policy effects in a contrast between the absence and presence of certain measures. As the general trends of language shift and assimilation in the Finno-Ugric republics continued, any positive change as the policy outcome is to be attributed to policy outputs. Yet, some rare positive changes were characteristic mostly of the 1990s, notably in education. Since the early 2000s, policy outputs have diminished. Recently, it was explicitly acknowledged that the agenda was only to lower the "intensity of ethnic and linguistic assimilation processes" (see State Program of Udmurtia 2013, Zamyatin 2014c). How could one discern whether and to what extent the revivalist policy hindered assimilation?

No consistent data on the dynamics in outcomes was available for all five republics. Similar data across the periods was systematically available for Mari El and Karelia, and for the latter also a long-term analysis (see Klementiev 2013). For Udmurtia and Komi, only occasional data were available. For Mordovia, there is the problem of a lack of data. Nonetheless, the analysis of the available data for Mari El and Karelia arguably makes it possible to provide a representative account of the processes in all republics, because these are two liminary cases in terms of their sociolinguistic situations as well as policy inputs, outputs and outcomes. In Karelia, language shift exceeds the similar processes in the other republics, while in Mari El, the processes are the slowest. At the same time, the ethnic elite in Karelia was more active in initiating ethnic mobilization than in the other 
republics (see Zamyatin 2013a). Accordingly, the two republics were more advanced than the other three republics in producing policy inputs and outputs, which can most visibly be seen in education, as discussed in the previous section.

\subsection{Indicators for policy outcomes}

In the framework of the policy-to-outcomes path, a change in language knowledge, language use and language attitudes would represent policy outcomes. However, general data provide only indirect evidence due to the complex causation of sociolinguistic processes. They are formed as the results, on the one hand, of activities directed at the creation of capacity, opportunity and desire to speak a language and, on the other hand, of effects of the social structure that lie outside the scope of policy, for example, intergenerational language transmission in families. Thus, I will in this section identify specific indicators for each activity in order to operationalize its effects for the purpose of evaluation.

Acquisition planning is the area in which effects are most accessible to operationalization, inter alia, because more has been done and more data is available. The policymakers in republics passed diverging measures pursuing the objective of increasing access to native language learning. Outcomes in education can be measured along such indicators as the number and percentage of language users at different levels of competence and in different age groups. The 2012 federal law on education allowed pupils to choose the native language and literature as an optional subject in the Unified State Exam, and the opportunity to take this exam was instituted in some republics (Zamyatin 2012a). Based on official data and some secondary sources, it will be possible in some years to qualitatively assess the level of language knowledge of pupils, inter alia, depending on the form of language learning. There are currently some individual studies, but assembling a systematic account across the republics remains a matter for further research.

Instead, this study assesses mostly the dynamics in the quantitative data about the language knowledge of pupils in general and school graduates in particular. Exploring language use, the study assesses language behaviour of pupils in various domains of daily life. The data on opinions about the need for reading and writing skills are also illustrative, because these are developed primarily in school. Exploring attitudes, the opinion 
about the appropriateness of compulsory teaching of titular languages and the need to study languages is informative of the policy outcome. Another indicator could be public opinion on whether schools' capacity to maintain and develop languages had changed, especially among teachers, pupils and their parents (see Grin 2003).

Regarding the creation of new opportunities for language use, the policymakers formulated the objective very narrowly to expand the use of the titular language only in official contexts. Despite their institutionalization, the titular languages were not used as working languages of the authorities in practice. At the same time, the titular languages were used to some extent in communication with citizens and in public services. Outcomes in official contexts can be measured by such indicators as the number and percentage of oral and written communications in requests, the percentage of official forms available or the percentage of civil servants who actually obtained language knowledge when attending language courses. However, no surveys have been conducted in the republics on these topics. An indirect way to reveal the change is to measure attitudes on the range of domains where people considered it appropriate to use their language, but no surveys have been conducted in this area, either. Insight into the change is provided by the data on public opinion about the measures needed to achieve a state of official bilingualism.

The objective in mass media was to sustain the level of supply. As there were few commercial outlets and channels using titular languages, the outcomes are directly attributable to policies. Outcomes in mass media can be measured using such indicators as sales figures of books and circulation figures of newspapers and journals, as well as audiences of TV and radio broadcasting. Alternatively, these can be converted into units of time spent on the consumption of media products. Regarding language use, it would be informative to examine the data on the change in habits related to reading, watching TV and listening to the radio as well as using the internet. For the exploration of attitudes, opinions about the demand for mass media are a relevant indicator.

\subsection{Sociolinguistic condition of the titular groups in post-Soviet times}

In what follows, I will again assess the general development in the sociolinguistic conditions of the titular groups along the outlined indicators. The data from the population censuses demonstrate that during the two 
post-Soviet decades, both the absolute numbers and, with some exceptions, the relative shares of the titular Finno-Ugric groups have continued to decrease gradually due to ever-accelerating language loss and ethnic assimilation. The data demonstrate that the shares of the titular groups among the total population remained relatively stable or continued to decrease in Udmurtia and Karelia from census to census, usually within a margin of $1 \%$ or, rarely, $2 \%$ (see Table 10 on the following page).

The last 1989 Soviet population census had a separate question on whether a person possessed knowledge of his or her native language, on the basis of his or her own personal assessment. The 2002 All-Russian population census asked no specific question on respondents' native language, only on their language knowledge. Therefore, no "official data" are available, only estimates. The 2010 All-Russian population census again asked the question on respondents' native language. At the same time, the share of those who did not answer the question about ethnicity and language increased in comparison to 2002 . Furthermore, it is a Soviet legacy of formulating the census questions that people sometimes report the language of their ethnic identity as their native language without having high or even any competence in that language.

According to the census data, language loss was somewhat slower during the first post-Soviet decade in comparison to the last Soviet decades. In the 1989 census, $88.4 \%$ reported knowledge of the Mari language among those who declared themselves ethnic Mari in the titular republic, along with $74.4 \%$ of Komi, $88.5 \%$ of Mordvins, $75.7 \%$ of Udmurts and only $51.5 \%$ of Karelians. According to estimates based on the data of the 2002 census, $84.2 \%$ of ethnic Mari in their titular republic reported knowledge of their language. The corresponding figures for other Finno-Ugric groups were $72.1 \%$ for Komi, $84.6 \%$ for Mordvins, $71.8 \%$ for Udmurts and $48.4 \%$ for Karelians. During the second post-Soviet decade, language loss intensified. According to calculations in 2010, only $75.8 \%$ of Mari, $65.4 \%$ of Komi, $68 \%$ of Mordvins, $55.8 \%$ of Udmurts and $36.8 \%$ of Karelians in their titular republics reported knowledge of their language. Outside the republics, language loss was more intensive, also among the Tatars, which indirectly indicates that the republics' language policies have had an impact.

\subsection{Language knowledge}

However, the census data are not sensitive to the fact that many people have double Russian-titular identities and claim the knowledge of two 


\begin{tabular}{|l|r|r|r|r|r|r|}
\hline Republic & Komi & Mari El & Mordovia & Udmurtia & Karelia & Tatarstan \\
\hline 1. Total population of the republic (thousands) \\
\hline Census 1989 & 1,251 & 749 & 963 & 1,605 & 790 & 3,641 \\
\hline Census 2002 & 1,018 & 728 & 889 & 1,570 & 716 & 3,779 \\
\hline Census 2010 & 901 & 696 & 834 & 1,521 & 643 & 3,786 \\
\hline 2. Titular group (thousands) \\
\hline Census 1989 & 291 & 324 & 313 & 496 & 79 & 1,756 \\
\hline Census 2002 & 256 & 312 & 283 & 460 & 65 & 2,019 \\
\hline Census 2010 & 202 & 290 & 333 & 410 & 45 & 2,012 \\
\hline 3. Share of the titular group in the total population of the republic (\%) \\
\hline Census 1989 & $23.3 \%$ & $43.3 \%$ & $32.5 \%$ & $30.9 \%$ & $10 \%$ & $48.5 \%$ \\
\hline Census 2002 & $25.2 \%$ & $42.9 \%$ & $31.9 \%$ & $29.3 \%$ & $9.2 \%$ & $52.9 \%$ \\
\hline Census 2010 & $23.7 \%$ & $43.9 \%$ & $40 \%$ & $28 \%$ & $7.4 \%$ & $53.2 \%$ \\
\hline 4. Report knowledge of their titular native language in the republic (\%) \\
\hline Census 1989 & $74.4 \%$ & $88.4 \%$ & $88.5 \%$ & $75.7 \%$ & $51.5 \%$ & $96.6 \%$ \\
\hline Census 2002 & $72.1 \%$ & $84.2 \%$ & $84.6 \%$ & $71.8 \%$ & $48.3 \%$ & $94.2 \%$ \\
\hline Census 2010 & $65.4 \%$ & $75.8 \%$ & $68 \%$ & $55.8 \%$ & $36.8 \%$ & $92.4 \%$ \\
\hline 5. Report knowledge of their native language in Russia (\%) & \\
\hline Census 1989 & $71.0 \%$ & $81.9 \%$ & $69.0 \%$ & $70.8 \%$ & $48.6 \%$ & $85.6 \%$ \\
\hline Census 2010 & $59.6 \%$ & $70.6 \%$ & $64.7 \%$ & $62.2 \%$ & $26.8 \%$ & $79.2 \%$ \\
\hline
\end{tabular}

Table 10: Dynamics in the absolute numbers and shares of the titular groups in relation to the total population of the Finno-Ugric Republics and their language retention rates (census data)

Sources: The data on native language knowledge in the republics for 2002 is from Finno-ugorskie narody (2008) and for 2010 from Program (2013), for Karelia from Klementiev (2013). The data on native language knowledge in Russia for 2010 is from Naselenie Rossii (2013)

native languages. The latter is possible because practically universal knowledge of Russian has been reached among titular groups, which also means that practically no titular monolinguals are left. Sociological surveys offer sight into the processes of language shift. For example, in Udmurtia there were $19.4 \%$ titular-language monolinguals in $1970,8.1 \%$ in 1989 and $1.6 \%$ in 2002. The number of unassimilated bilinguals and assimilated bilinguals remained relatively stable and were, respectively, $68.3 \%$ and $3.8 \%$ in 1970, 
$67.6 \%$ and $4.5 \%$ in 1989 , and $65 \%$ and $5.2 \%$ in 2002 . At the same time, the number of assimilated monolinguals increased from $8.5 \%$ in 1970 to $19.8 \%$ in $1989,28.2 \%$ in 2002 and $44 \%$ in 2010 (see Lallukka 1990: 200-207; Williams et al. 2008: 54; Vorontsov 2013).

In contrast, the officials in Mari El reported based on a 1999 survey that the share of the Mari who declared Mari as their native language had for the first time increased within the decade, from about $80 \%$ to $85.8 \%$ (Yanalov 2000). According to the available data from the sociological surveys, $79.5 \%$ of the Mari respondents reported Mari as their native language in $1985,88.1 \%$ in $1994,81.8 \%$ in $2001,76.4 \%$ in 2011 and $79.2 \%$ in 2012 (the 1994 data hereafter for Meadow Mari, by far the largest Mari subgroup, Mezhnatsionalnye otnosheniia 1995, 2002, Sotsiologicheskie issledovaniia 2013). However, it must be noted that the jump in the 1994 figures for Mari as one's native language is also probably the result of a possible change in the survey methodology, when respondents were discouraged from indicating two native languages. Namely, the share of respondents who reported both Mari and Russian as their native languages was $13.8 \%$ in 1985 , $0.6 \%$ in $1994,11.1 \%$ in $2001,15.4 \%$ in 2011 and $12.9 \%$ in 2012 . The share of those Mari who reported Russian as their native language was $6.1 \%$ in 1985 , $8.7 \%$ in $1994,6.2 \%$ in 2001, $7.3 \%$ in 2011 and $7.8 \%$ in 2012 (see Kudriavtseva \& Shabykov 2002, Shabykov et al. 2014b).

This fluctuation also demonstrates that the question on one's native language conveys information about linguistic identity and attitudes rather than language knowledge (for the data on different understanding of the concept of native language among the Mari, see, for example, Shabykov et al. 2014b). The question about language competence is more revealing. It seems that the high level of competence among the Mari also remained relatively stable. Among those Mari respondents in the republic who reported Mari as their native language, $78.3 \%$ could speak, read and write in the language in $1994,75.4 \%$ in $2001,78.3 \%$ in $2007,79.7 \%$ in 2011 and $76.6 \%$ in 2012 (Mezhnatsionalnye otnosheniia 1995, 2002, Finno-ugorskie narody 2008, Sotsiologicheskie issledovaniia 2013, Shabykov \& Kudriavtseva 2015). The level of competence among the titular groups in the other republics was lower. According to data from the survey conveyed in 2007, the level of competence in titular languages among those who reported the titular language as their first language further dramatically decreased when compared to the late Soviet period (see Table 2 on page 266, Table 11 on the following page). 


\begin{tabular}{|l|r|r|r|r|r|}
\hline Republic & \multicolumn{1}{|c|}{ Komi } & Mari El & Mordovia & Udmurtia & Karelia \\
\hline $\begin{array}{l}\text { Speech, Reading, } \\
\text { Writing }\end{array}$ & 73.4 & 78.3 & 75.1 & 68.6 & 66 \\
\hline Speech, Reading & 10.2 & 5.2 & 7.2 & 8.6 & 10.2 \\
\hline Speech & 7.5 & 4.4 & 9.7 & 10.3 & 12.6 \\
\hline $\begin{array}{l}\text { Understanding } \\
\text { freely }\end{array}$ & 3.9 & 7.6 & 3.6 & 5.1 & 3.4 \\
\hline $\begin{array}{l}\text { Understanding } \\
\text { the topic }\end{array}$ & 4.5 & 3.1 & 4.1 & 5 & 6.8 \\
\hline Undecided & 0.6 & 1.3 & 0.3 & 2.4 & 1 \\
\hline
\end{tabular}

Table 11: Command of native languages by component in 2007 (\%, adapted from Finno-ugorskie narody 2008: 256)

Thus, respondents' knowledge of Russian was much better than their knowledge of native language, so that more titular representatives were more fluent in Russian than in native language. This becomes even clearer if one includes in the data also those who reported a titular ethnic identity but indicated Russian as their (first) native language. For example, the data of the 2002 sociological survey in Karelia demonstrated that only $23.8 \%$ of Karelian respondents could speak, read and write, $29.7 \%$ could freely speak but not read or write, $17.5 \%$ understood the language and could make themselves understood, $18.4 \%$ knew some words and $10.6 \%$ did not know Karelian at all. By 2008, the share of those Karelian respondents who could speak, read and write had decreased to $19.9 \%$. About a third of Komi, Udmurts and Mordvins reported the same. In contrast, still more than half of the Mari respondents reported a high level of command of their native language (Table 12).

Surveys consistently find a very low level of knowledge of the titular languages among ethnic Russians, which rarely falls within the margins of more than one to two percent and has not significantly changed over time. In practice, only a relatively small portion of Russian schoolchildren have learned the titular languages despite the introduction of their compulsory study. In contrast, virtually all Russian schoolchildren in Tatarstan learned Tatar. The republic's authorities reported an increase in the number of Russians with at least some knowledge of Tatar from $18 \%$ in 1989 to $44.1 \%$ in 2010 , including an increase in fluency among Russian speakers 


\begin{tabular}{|l|r|r|r|r|r|}
\hline Republic & \multicolumn{1}{|c|}{ Komi } & Mari El & Mordovia & Udmurtia & \multicolumn{1}{c|}{ Karelia } \\
\hline $\begin{array}{l}\text { Speech, Reading, } \\
\text { Writing }\end{array}$ & 35.9 & 55.6 & 37.6 & 37.2 & 19.9 \\
\hline Speech, Reading & 9.9 & 6.3 & 7.7 & 6.3 & 13.6 \\
\hline Speech & 8.7 & 5.7 & 9.7 & 13.4 & 13.6 \\
\hline $\begin{array}{l}\text { Understanding } \\
\text { freely }\end{array}$ & 4.2 & 6.8 & 6.6 & 7.4 & 8.7 \\
\hline $\begin{array}{l}\text { Understanding } \\
\text { the topic }\end{array}$ & 6.3 & 5 & 6.4 & 12.5 & 20.9 \\
\hline Undecided & 0 & 1.8 & 0.6 & 2.4 & 0 \\
\hline
\end{tabular}

Table 12: Command of titular languages by titular groups by component in 2007 (\%, adapted from Finno-ugorskie narody 2008: 256)

from $1.1 \%$ in 1989 to $12 \%$ in 2010 . At the same time, no noticeable changes have been traced in their actual communicative behaviour (State Program of Tatarstan 2013).

The data on the language competence of pupils is illustrative of some progress. The 2002 data on the Karelian pupils in the titular republic demonstrated that in comparison with the data of the 1996 survey, the share of pupils with a good knowledge of the language somewhat increased and the share of schoolchildren with a satisfactory knowledge significantly increased. In the pupils' own assessment, the shares of those pupils who assessed their knowledge of Karelian proper as good grew from $4.2 \%$ in 1996 to $5 \%$ in 2002 and those who considered it satisfactory from $62.5 \%$ to $75 \%$, while those who assessed their knowledge as unsatisfactory decreased from $29.2 \%$ to $15 \%$. Among the pupils speaking Olonets Karelian, the shares of those who assessed their knowledge as good grew from none in 1996 to $3.6 \%$ in 2000 and as satisfactory from $76.5 \%$ to $92.9 \%$, while those assessing it as unsatisfactory decreased from $23.5 \%$ to $3.6 \%$. Despite the positive dynamics, the relatively low level of knowledge complicated its actual use (Klementiev 2013: 154-158). In 2007, 32\% of those Karelian pupils who studied the language reported that they could speak, read and write, $42 \%$ understood the language but did not speak and $25 \%$ knew only some words (Predvaritelnye itogi 2007). 
The 2000 data on Mari pupils demonstrated that only $53.1 \%$ of those graduating from the 9th and 11th grade could speak, read and write in the Mari language. Among students obtaining primary and secondary vocational education, the shares were, respectively, $37.3 \%$ and $38.8 \%$, and among students obtaining higher education degrees, the figure was 53\% (see Kudriavtseva \& Shabykov 2002). In 2011, the share of those who could speak, read and write in the Mari language and had incomplete secondary education was $42.4 \%$ (Sotsiologicheskie issledovaniia 2013). Therefore, the Mari youth cohorts also had a lower competence in their native language than the older generations, and that level continued to decline, the primary reason for this being the fact that Russian was used as the language of instruction.

\subsubsection{Language use}

A striking trend is the reversal in the patterns of bilingualism across domains when compared to the patterns during Soviet times (see Table 2 on page 266). Recently, Russian was much more often used not only at work and with friends but also at home. For example, $48.1 \%$ of Tatar respondents in the titular republic in 1994 used their native language at home, 14.1\% at work and $12.6 \%$ for reading newspapers; $29.6 \%$ used two languages at home, $37.5 \%$ at work and $44.8 \%$ for reading newspapers, while the rest used Russian (Musina 2004). In the same year, $47 \%$ of Udmurts used their native language at home, $15.7 \%$ in their studies and $31.1 \%$ at work (see Guboglo \& Smirnova 2001: 395). In 2000, 29\% used their language at work (see Etnosotsiologicheskoe issledovanie 2000). In 2003, 42.3\% used their native language at home, $36.7 \%$ with friends and $23.5 \%$ at work (see Natsionalnye otnosheniia 2003). In 2007, the share of the Udmurt respondents who used their language at home was $12 \%$, with friends $8.4 \%$ and at work $3.9 \%$. In general, less than half respondents across the republics used their native language even at home (see Table 13).

Further, the 1997 cross-regional survey showed that $46.2 \%$ of Udmurt and $18 \%$ of Karelian respondents read fiction by authors from the titular nationality in their languages (Hudaverdian 1998). The 2007 survey in Mordovia showed that $17.8 \%$ of Mordovian respondents read fiction by titular authors in their languages and $36.6 \%$ in the titular and Russian languages. A total of $33.5 \%$ regularly, 52\% rarely and $14.5 \%$ never watched TV and listened to the radio, while $32.5 \%$ regularly, $52 \%$ rarely and $13.5 \%$ never 


\begin{tabular}{|c|c|c|c|c|c|}
\hline Republic & Komi & Mari El & Mordovia & Udmurtia & Karelia \\
\hline \multicolumn{6}{|c|}{ Native language } \\
\hline At home & 21.9 & 51.4 & 24.3 & 12 & 10.7 \\
\hline With friends & 14.1 & 30 & 13.8 & 8.4 & 7.3 \\
\hline At work & 9.9 & 20.4 & 5.8 & 3.9 & 4.9 \\
\hline \multicolumn{6}{|c|}{ Russian and native language equally } \\
\hline At home & 10.2 & 13.6 & 12.7 & 18.2 & 10.7 \\
\hline With friends & 13.2 & 28.2 & 20.2 & 18.4 & 9.2 \\
\hline At work & 9.9 & 21.4 & 13.3 & 10.8 & 8.3 \\
\hline \multicolumn{6}{|l|}{ Russian } \\
\hline At home & 62.9 & 29.8 & 61.6 & 69.5 & 78.2 \\
\hline With friends & 68.9 & 36.8 & 65.2 & 73.1 & 83.5 \\
\hline At work & 72.2 & 53.3 & 78.7 & 82 & 85.4 \\
\hline
\end{tabular}

Table 13: Use of native languages and Russian by the titular groups in their republics in various domains of daily life in 2007 (\%, adapted from Finnougorskie narody 2008: 172-173)

read periodicals in the titular languages (Natsionalnye fondy 2007). In $2000,17 \%$ of the Udmurt respondents read periodicals mostly in their language, $45 \%$ mostly watched regional programs in that language on TV and $49 \%$ mostly listened to regional programs in radio broadcasting in their language (Etnosotsiologicheskoe issledovanie 2000). In 2003, 22.6\% of the Udmurt respondents reported that they (regularly) read periodicals, $26.2 \%$ watched TV and $29.6 \%$ listened to radio broadcasting in the language (Natsionalnye otnosheniia 2003). In 2003, $40.8 \%$ of the Komi respondents regularly and $39.6 \%$ irregularly watched TV and listened to radio broadcasting in the language, while in 2006 only $29.1 \%$ did so regularly and $54.9 \%$ irregularly (Finno-ugorskie narody 2008: 167). Thus, the dynamics reveal the diminishing of the audience. By 2007 , similar patterns were characteristic also for the other titular groups (see Table 14 on the following page).

In both cases, the Mari reported using their language more than others. In $1994,49 \%$ of the Mari respondents regularly, $31.5 \%$ irregularly, $16.3 \%$ rarely and only $3.2 \%$ never watched TV; $43.8 \%$ regularly, $33.3 \%$ irregularly, $15.3 \%$ rarely and $7.6 \%$ never listened to radio broadcasting in the native language. In $2001,34.5 \%$ regularly, $32.8 \%$ irregularly and $21.4 \%$ rarely watched TV; $29.2 \%$ regularly, $32.4 \%$ irregularly and $16.4 \%$ rarely listened to radio 


\begin{tabular}{|l|r|r|r|r|r|}
\hline Republic & \multicolumn{1}{|c|}{ Komi } & Mari El & Mordovia & Udmurtia & Karelia \\
\hline Reading of periodical publications \\
\hline Read regularly & 15.3 & 24 & 5.8 & 12 & 13.6 \\
\hline Read occasionally & 20.7 & 34.7 & 17.4 & 23 & 26.7 \\
\hline Do not read & 40.4 & 25.6 & 58.3 & 59.5 & 56.3 \\
\hline $\begin{array}{l}\text { Do not have the } \\
\text { opportunity }\end{array}$ & 4.8 & 2.3 & 5.5 & 2.7 & 2.4 \\
\hline Undecided & 0 & 0.8 & 0 & 2.7 & 1 \\
\hline Watching/listening to TV and radio broadcasting & & & \\
\hline $\begin{array}{l}\text { Watch/listen } \\
\text { regularly }\end{array}$ & 29.6 & 33.4 & 14.4 & 29.2 & 19.4 \\
\hline $\begin{array}{l}\text { Watch/listen } \\
\text { occasionally }\end{array}$ & 37.1 & 38.9 & 39 & 38.3 & 49 \\
\hline Do not watch/listen & 11.7 & 27.3 & 31.5 & 27.3 & 28.2 \\
\hline $\begin{array}{l}\text { Do not have the } \\
\text { opportunity }\end{array}$ & 2.4 & 3.6 & 2.2 & 3.6 & 3.4 \\
\hline Undecided & 0.3 & 1.7 & 0 & 1.7 & 0 \\
\hline
\end{tabular}

Table 14: The reading of periodical publications and watching/listening to TV and radio broadcasting in the titular languages in 2007 (\%, adapted from Finno-ugorskie narody 2008: 256)

broadcasting (Mezhnatsionalnye otnosheniia 1995, 2002). In 2006, 33.4\% regularly and $38.9 \%$ occasionally watched and listened to the Mari-language TV and radio broadcasting, while now $27.3 \%$ did not watch or listen at all. The Mari respondents also reported that they use their native language at home, regularly or occasionally read newspapers in that language in slightly more than half of cases. However, a closer look at the dynamics of language use in family life in Mari El over the course of a decade reveals that speakers used the language mostly with their parents (see Table 15).

If one follows the dynamics of communications with the next generation, $65.6 \%$ of Mari spoke their native language with their children in 1973. In 1985, 43.4\% of Mari spoke their native language with their schoolaged children. By 1994, the respective share of school-aged Mari children had decreased to $23.3 \%$. In 2001, the data showed some increase in native language use up to $34.6 \%$. In 2011, $15.7 \%$ still spoke Mari to their schoolaged children, which means that there was a significant decrease, although 


\begin{tabular}{|c|c|c|c|c|c|}
\hline & $\begin{array}{l}\text { With One's } \\
\text { Parents }\end{array}$ & $\begin{array}{l}\text { With One's } \\
\text { Spouse }\end{array}$ & $\begin{array}{l}\text { With One's } \\
\text { Children }\end{array}$ & $\begin{array}{l}\text { of School } \\
\text { Age }\end{array}$ & $\begin{array}{l}\text { of Preschool } \\
\text { Age }\end{array}$ \\
\hline $\begin{array}{l}\text { 1994: } \\
\text { Russian }\end{array}$ & 11 & 14.9 & $\mathrm{n} / \mathrm{a}$ & 14 & 13.8 \\
\hline $\begin{array}{l}\text { 1994: } \\
\text { both }\end{array}$ & 19.3 & 18.6 & $\mathrm{n} / \mathrm{a}$ & 20.7 & 20 \\
\hline $\begin{array}{l}\text { 1994: } \\
\text { Mari }\end{array}$ & 62.7 & 45.9 & $\mathrm{n} / \mathrm{a}$ & 23.3 & 25.6 \\
\hline $\begin{array}{l}\text { 2001: } \\
\text { Russian }\end{array}$ & 13 & 19.4 & $\mathrm{n} / \mathrm{a}$ & 21.8 & 18.8 \\
\hline $\begin{array}{l}\text { 2001: } \\
\text { both }\end{array}$ & 10.1 & 15.2 & $\mathrm{n} / \mathrm{a}$ & 13.1 & 6.9 \\
\hline $\begin{array}{l}\text { 2001: } \\
\text { Mari }\end{array}$ & 70.4 & 64.2 & $\mathrm{n} / \mathrm{a}$ & 34.6 & 34 \\
\hline $\begin{array}{l}\text { 2011: } \\
\text { Russian }\end{array}$ & 15.7 & 21.5 & $\mathrm{n} / \mathrm{a}$ & 20.7 & 22.9 \\
\hline $\begin{array}{l}\text { 2011: } \\
\text { both }\end{array}$ & 6.5 & 6.1 & $\mathrm{n} / \mathrm{a}$ & 11.5 & 7.5 \\
\hline $\begin{array}{l}\text { 2011: } \\
\text { Mari }\end{array}$ & 68.9 & 41.4 & $\mathrm{n} / \mathrm{a}$ & 15.7 & 17.3 \\
\hline
\end{tabular}

Table 15: Language used in communication by adult Mari with members of their family in 1994, 2001 and 2011 (\%, adapted from Mezhnatsionalnye otnosheniia 1995, 2002, Sotsiologicheskie issledovaniia 2013)

not so steep, if one takes into account that about half of respondents did not answer the question. Continued migration of Mari to urban areas still played the most important role in interrupting intergenerational language transmission: in 2001, 73.3\% of Mari in Yoshkar-Ola spoke with their children in Russian, $8.3 \%$ in Mari and $15 \%$ in both languages, while in the villages $9.2 \%$ of Mari spoke with their children in Russian, $73.2 \%$ in Mari and $16.9 \%$ in both languages. In 2002, 60\% of ethnic Mari in the republic were rural dwellers. Thus, intergenerational language transmission was interrupted in a significant portion of families.

Again, the trends are best illustrated by the data on young people. In Karelia in the 1990s, the use of Russian among Karelian pupils in various domains of daily life decreased by roughly half and the use of the native language at home and in school increased by a fifth. The shares of those who used only Russian in school decreased from $71 \%$ in 1996 to 33\% in 
2002, those who used only Russian at home from $45 \%$ to $24.4 \%$ and those who used only Russian in other contexts from $57 \%$ to $25.7 \%$. The shares of those who used mostly Russian in school increased from $28 \%$ to $39.7 \%$, decreased at home from $47 \%$ to $38.5 \%$ and decreased in other contexts from $43 \%$ to $33.3 \%$. The shares of those who started to use native Karelian more often in school increased from $1 \%$ to $20.5 \%$ and at home from $8 \%$ to $20.5 \%$. A total of $14.1 \%$ used Karelian more in other contexts in 2002. The shares of those who used mostly Karelian were $6.4 \%$ in school, $16.7 \%$ at home and $2.6 \%$ in other contexts in 2002. Thus, despite some positive shifts, Russian continued to be the most used language (Klementiev 2013: 135-145). A 2007 survey demonstrated that in the following years, the trends reversed and Karelian continued to rapidly lose its ground also in the family, which virtually lost its function as the vehicle for intergenerational transmission of the language (Predvaritelnye itogi 2007).

\subsubsection{Language attitudes concerning compulsory study, knowledge and official use}

The study of the evolution in public attitudes towards languages provides a shortcut to understanding the change in the sociolinguistic situation. What did the public think about the compulsoriness of the titular languages? Some sociological research studies have explored popular opinion on linguistic issues in the public sphere in Russia's republics. For example, Dmitry Gorenburg (2003: 157-158) measured public support for cultural nationalism among the titular groups of ethnic republics by examining their language attitudes based on the data of the 1993 Western surveys (Colton and Laitin) and a 1994 Russian survey (Institute of Social-Political Research of the Russian Academy of Sciences) (see Table 16).

In Russia's ethnic republics, support appeared to be the lowest among the titular groups of the Finno-Ugric republics, as witnessed by the following data. According to the 1993 data used by Gorenburg, the single titular state language was supported by $13 \%$ among Karelians, up to $18 \%$ among Udmurts, $23 \%$ among Mari, and $26 \%$ among both Komi and Mordvins. Compulsory knowledge of the titular languages by all inhabitants was supported by $31 \%$ of Mari and Mordvins, $34 \%$ of Komi and Karelians, and $36 \%$ of Udmurts. Support for compulsory study of the titular state languages in all schools was expressed by $36 \%$ of Udmurts, $37 \%$ of Mordvins, $42 \%$ of Mari, $43 \%$ of Komi and $52 \%$ of Karelians. 


\begin{tabular}{|c|c|c|c|c|c|c|c|}
\hline Republic & Komi & Mari El & Mordovia & Udmurtia & Karelia & Tatarstan & $\begin{array}{l}\text { Average } \\
\text { for all of } \\
\text { Russia's } \\
\text { republics }\end{array}$ \\
\hline \multicolumn{8}{|c|}{ Should the titular language be the sole official language in ethnic republics? } \\
\hline $\begin{array}{l}\text { Completely } \\
\text { or partially } \\
\text { agree }\end{array}$ & 26 & 23 & 26 & 18 & 13 & 29 & 41 \\
\hline $\begin{array}{l}\text { Completely } \\
\text { or partially } \\
\text { disagree }\end{array}$ & 60 & 62 & 59 & 70 & 72 & 59 & 48 \\
\hline \multicolumn{8}{|c|}{ Should all inhabitants of an ethnic republic know the titular language of that republic? } \\
\hline Agree & 34 & 31 & 31 & 36 & 34 & 44 & 49 \\
\hline Disagree & 52 & 50 & 55 & 47 & 53 & 32 & 16 \\
\hline \multicolumn{8}{|c|}{ Should titular-language study be compulsory in all schools in ethnic republics? } \\
\hline $\begin{array}{l}\text { Completely } \\
\text { agree }\end{array}$ & 43 & 42 & 37 & 36 & 52 & 66 & 65 \\
\hline $\begin{array}{l}\text { Only if } \\
\text { majority in } \\
\text { region }\end{array}$ & 22 & 17 & 24 & 30 & 17 & 10 & 17 \\
\hline $\begin{array}{l}\text { Completely } \\
\text { disagree }\end{array}$ & 24 & 30 & 28 & 24 & 24 & 10 & 12 \\
\hline
\end{tabular}

Table 16: Attitudes of titular groups to the official status of titular languages and their compulsoriness in 1993-1994 (\%, adapted from Gorenburg 2003: 235-240)

Note: the rest gave no opinion.

In the early 1990s, sociological surveys in republics presented a somewhat different picture. The 1994 sociological survey in Tatarstan showed that $64.3 \%$ of Tatars and $58.3 \%$ of Russians supported the designation of two state languages of Tatarstan, $21.2 \%$ of Tatars and $2.9 \%$ of Russians supported Tatar as the single state language, and $87.1 \%$ of Tatars and $71 \%$ of Russians agreed that government employees should command both languages (Iskhakova 2002). The 1994 survey in Mari El found that 31.7\% of Mari and $2.2 \%$ of Russians supported the single titular state language, while $56.6 \%$ of Mari and $41.5 \%$ of Russians supported two state languages and $6.8 \%$ of Mari and $50.7 \%$ of Russians only Russian. A total of $35.4 \%$ of Mari and 
$10.2 \%$ of Russians agreed with the need for compulsory knowledge of the titular state language by all inhabitants, while $31.1 \%$ of Mari and $58.1 \%$ of Russians disagreed. Altogether $25.3 \%$ of Mari and $24.6 \%$ of Russians agreed with such a need only for leading officials and workers in certain professions. A total of $59.2 \%$ of Mari and $21.8 \%$ of Russian respondents agreed that the study of titular state language should be compulsory in all schools of the republic, while $25.1 \%$ of Mari and $61.9 \%$ of Russians disagreed (Mezhnatsionalnye otnosheniia 1995).

The 1994 sociological survey in Udmurtia revealed a similar picture: $64.6 \%$ of Udmurts and $46.4 \%$ of Russians supported two state languages (Shkliaev 1998: 163). In a survey carried out in Komi in 1996, 22.5\% of Komi pupils agreed and $36.6 \%$ somewhat agreed with the compulsory study of the titular state languages by all pupils, while a quarter disagreed. Among the Russian pupils, $6.7 \%$ agreed and $17 \%$ somewhat agreed (Opros 1996, Mironova 2012). In Mordovia in 1991, only $6.7 \%$ of Mordvins agreed that Erzia and Moksha should be the only state languages of the republic while $57.1 \%$ disagreed. The same survey found that $17.9 \%$ of Mordvins agreed with their compulsory study while $49 \%$ disagreed, and $17.2 \%$ agreed with their compulsory knowledge and 71.8\% disagreed (Shilov 2002).

By the early 2000s, the attitudes had somewhat changed. In 2001, 35.9\% of Mari and $6.3 \%$ of Russians agreed with the need for compulsory knowledge of the titular languages by all inhabitants, while $18.4 \%$ of Mari and $60.8 \%$ of Russians disagreed. Further, $37.1 \%$ of Mari and $24.8 \%$ of Russians agreed with such need only for leading officials and workers in certain professions. A total of $62.1 \%$ of Mari and $19.4 \%$ of local Russians were for compulsory teaching of the titular state language to all pupils, while $23.7 \%$ of Mari and $65.7 \%$ of Russians disagreed (Mezhnatsionalnye otnosheniia 2002: 110; Sharov 2002, 2008).

In 2004, 35.8\% of Komi and $13.3 \%$ of local Russian respondents were for compulsory teaching of their titular state languages to all pupils, while $48.4 \%$ and $59.8 \%$ were for free choice, according to the data of the research institute (Opros 2004, Mironova 2012). According to data from the 2007 survey commissioned by the ministry of nationalities affairs, $58 \%$ of Komi and $26.6 \%$ of Russians were for compulsory teaching (Long-term Program 2009). In 2002, 31\% of Udmurt respondents completely and $28.8 \%$ partially agreed with compulsory teaching, while only $3.4 \%$ of local Russians completely and $14.1 \%$ partially agreed (Smirnova 2002: 505). According to a 2003 survey, $46.7 \%$ of Udmurts and $16.1 \%$ of Russians were for compulsory teaching of Udmurt to all pupils (Natsionalnye otnosheniia 2003). 
According to the 2002 survey carried out in Karelia, 12.5\% of Karelian respondents agreed with the need to designate Karelian as a state language of the republic and believed it should be done because the language would be able to perform such a function. A total of $17.4 \%$ believed it should be done even if the language would not be able to perform the function. In addition, 21.8\% believed it should be done in the future. Altogether $21.5 \%$ were against the official designation of the language. When asked whether Karelian should be taught in school, 74\% agreed and 13\% disagreed (Klementiev 2013: 143-144).

In 2012, 93.6\% of Tatars and $69.1 \%$ of Russians in Tatarstan agreed with the need for compulsory knowledge of both state languages by government employees, while $91.4 \%$ of Tatars and $63.2 \%$ of Russians felt it should be compulsory among service-sector workers in the same period (State Program of Tatarstan 2013). In contrast, $54.2 \%$ of Mari and $16.9 \%$ of Russians agreed in 2012 with the need for compulsory knowledge of the titular languages by all inhabitants. A total of $23 \%$ of Mari and $29.5 \%$ of Russians agreed with such need only for leading officials and workers in certain professions, while $11.2 \%$ of Mari and $33.9 \%$ of Russians disagreed. The same survey found that $53.6 \%$ of Mari and $20.9 \%$ among local Russians thought that compulsory teaching of Mari as a state language in all education institutions was the way to increase the prestige of the language (Shabykov \& Kudriavtseva 2015).

When asked about their opinion on measures needed in order to achieve a state of official bilingualism and to raise the prestige of the titular languages, more Udmurt respondents were for the introduction of Udmurt in public places than for its compulsory official use: in 2003, 90.7\% were for the opening of free language courses, $80.7 \%$ for the renewal of Udmurt lessons on TV and radio, $75.3 \%$ for the translation of official names of legal entities into two languages, $64.1 \%$ for bilingual signposts, $60.2 \%$ for the establishment of a list of professions with the requirement of compulsory knowledge of two languages and $46.7 \%$ for the introduction of Udmurt as a compulsory subject for all secondary school pupils.

Similarly, the Mari respondents in 2012 thought that the following actions were needed: $60 \%$ were for the creation of a satellite TV channel Mariiskii Mir, 58.2\% for the popularization of the Mari culture on the Russian central TV channels and $53.6 \%$ for compulsory teaching of Mari as a state language in all educational institutions. Further, 35.3\% were for the production of movies, documentaries and cartoons in the Mari language, 
24.5\% for announcements in two languages in public places, $21.2 \%$ for the use of advertisements in Mari, $20.7 \%$ for the creation of a Mari-language online TV channel and $16.5 \%$ for the introduction of financial bonuses to those public officials who learn the language. The support of the local Russians for these actions was on average half of these levels (respectively, $31.1 \%, 28.1 \%, 20.9 \%, 17.3 \%, 13.3 \%, 10.6 \%$ and $8.2 \%$ ), with the exception of the last measure, as even more Russian respondents than Mari, or 17.1\%, were in favour of the bonuses (Shabykov \& Kudriavtseva 2015).

Among youth who were studying (ages 18-23), the following reasons were given for the limited scope of official bilingualism: $71.4 \%$ of Mari and $58.6 \%$ of Russians thought it was due to a lack of knowledge of two languages by all inhabitants of the republic. Further, 53.6\% of Mari and $20.7 \%$ of Russians saw it as the result of a lack of respect towards the Mari language (while $3.6 \%$ of Mari and $6.3 \%$ of Russians saw a lack of respect for Russian), $25 \%$ and $51.7 \%$, respectively, due to a lack of desire to study the language, $25 \%$ and $10.3 \%$ because was not a working language of public authorities, $21.4 \%$ and $17.2 \%$ because of a lack of contemporary textbooks, $14.3 \%$ and $17.3 \%$ because there were not enough opportunities to study in Mari, $7.1 \%$ and $10.3 \%$ because Mari is not a language of management of public affairs and the same amount because of a lack of financial resources.

Among Mari youth who were studying, $57.1 \%$ saw a solution in bilingualism of mass media, $40 \%$ believed official events had to begin with greetings in two languages, $32.1 \%$ were for compulsory teaching of Mari in all educational institutions, $21.4 \%$ for compulsory language courses for public officials and 7.1\% for official management of public affairs in two languages. Support for these measures among the Russian youth was on average one third lower (respectively, $41.4 \%, 24.9 \%, 17.2 \%$ and $13.8 \%$ ), except for the last measure, which was supported by $17.2 \%$ (Shabykov et al. 2014a).

\subsubsection{Language attitudes and incentives for free choice}

Given the prevailing negative attitudes to the compulsoriness of titular language use, it is relevant to study attitudes to voluntary language use in wider social contexts. The indicators that are informative of people's willingness to use languages include beliefs about the future prospects of the language and its role as a marker of identity, public value attached to the language and the desire of parents for their children to know their language. In addition, the data on opinions about the adequacy of policy 
measures in general and of school performance in particular directly shed light on the policy impact. When asked for their opinion about the future of the languages in the 2007 cross-regional survey, slightly more than half among the Mari and Karelian respondents and about two thirds of respondents in the other republics thought that the languages would remain at the current level, while a noticeable portion thought that the languages would gradually disappear (Finno-ugorskie narody 2008: 191-192).

The perception of language as the main marker of ethnic identity in Tatarstan increased from $54.1 \%$ among the Tatars and $56.8 \%$ among the Russians in 1989 to, respectively, $71.8 \%$ and $66.6 \%$ in 2000 , and to $79 \%$ and $72.5 \%$ in 2010. In Mari El, the respective numbers also increased in the 1990 s but decreased in the 2000 s from $79.3 \%$ among the Mari and $72 \%$ among the Russians in 2001 to, respectively, $75 \%$ and $65.7 \%$ in 2010. Scholars found a correlation between the perception of the language as an ethnic value that defines one's attachment to the group and levels of language competence (Shabykov et al. 2014b).

The opinions of the Mari on the public value of their language, that is, its (in)appreciation in the wider society, were divided almost equally between those who saw a high or relatively high value, on one hand, and those who perceived a low or not high enough value, on the other hand. In the other four republics, the prevailing opinion was that the titular languages had a low or not a high enough public value. For example, among the Komi respondents in 2003, 9.9\% thought that the language had a high value and 23.4\% a sufficiently high value. Among the ethnic Russian respondents in Komi, the respective shares were only $3.4 \%$ and $13.8 \%$. By 2007 , only $5.9 \%$ of the Komi respondents thought that the language had a high value and $18 \%$ a sufficiently high value (Finno-ugorskie narody 2008: 178-182).

In $1994,87.2 \%$ of the Mari respondents believed that their children needed to know their native language and only 1.2\% disagreed; in 2001, 87\% of the Mari respondents still thought so, while $7.8 \%$ disagreed (Mezhnatsionalnye otnosheniia 1995, 2002). In 2007, 79.4\% of the Mari respondents agreed with the statement, including $48.6 \%$ of those who also thought it was desirable for children to read and write in the language, $23.5 \%$ who thought it was desirable to speak and understand and 7.3\% who thought it was enough to understand speech, while $6.8 \%$ said there was no need. In 2011, $86.8 \%$ of the Mari respondents agreed, 2.5\% disagreed and 9\% were indifferent (Sotsiologicheskie issledovaniia 2013). In the other republics, the respective shares in 2007 were somewhat lower, with $16 \%$ of Udmurts 
and $12.1 \%$ of Mordvins feeling there was no need for their children to learn the languages (Finno-ugorskie narody 2008: 175-176).

The respondents in different republics held diverging opinions on policy effects. A total of $53.1 \%$ of the Mordvin respondents likely or definitely thought that the state undertook sufficient measures for the development of languages. In contrast, $58.7 \%$ of Komi and $41.5 \%$ of Udmurts likely or definitely thought the state did not undertake sufficient measures. The opinions of the Mari were again divided nearly equally. No data on Karelians were provided (Finno-ugorskie narody 2008: 189-192).

Another issue that comes close to revealing policy effects is the data on public opinion about the role of school performance in maintaining and developing the languages. Here, again, opinions in the different republics diverged. About a third of respondents in Karelia and Mordovia (36.9\% and $32.9 \%$, respectively) and slightly less than a third but still the plurality in Udmurtia (29\%) thought that the school's capacity to develop the languages had definitely increased in the last years. In Komi and Mari El, the plurality of about a quarter (respectively, 22.2\% and 25.6\%) thought that the capacity had not changed. In Mari El, a somewhat larger share of respondents thought that the capacity of school had definitely increased (19.3\%) than that it had definitely decreased (13.6\%). In Komi, these shares were spread more or less equally (Finno-ugorskie narody 2008: 184-188).

In general, a correlation was found between the level of language competence of the respondents and the desire of parents for their children to learn the language. This brings us back to the focus on schoolchildren. In the 1990s, language attitudes among pupils in Karelia displayed some positive changes. The share of Karelian pupils who were still "ashamed of speaking their native language" decreased from $42 \%$ in 1996 to $19.2 \%$ in 2002, while the share of those who felt less shame increased from $57.1 \%$ to $70.5 \%$. The opinion of native language teachers about school performance concerning teaching native languages in the 1990s changed in such a way that the share of those teachers who believed nothing had to be changed because enough was done decreased from $15 \%$ in 1996 to $7.7 \%$ in 2002, the share of those who wanted school to increase the number of teaching hours decreased form $69 \%$ to $67.9 \%$, the share of those who wanted school to start teaching several subjects in Karelian increased from $10 \%$ to $15.4 \%$ and the share of those who wanted school to start teaching most subjects in primary school in Karelian increased from 3\% to 9\%. However, almost two thirds of teachers pointed to the low preparedness of the school to start teaching 
several subjects in the language. Therefore, the measures taken for school development were assessed as insufficient (Klementiev 2013: 135-145).

After the start of the 2007 education reform, Russian scholars conducted some cross-regional sociological surveys in order to determine the demand for "ethnocultural education", exploring language attitudes of pupils, their parents and experts, including school teachers and administrators (see Etnokulturnoe obrazovanie 2010, Mezhetnicheskie otnosheniia 2016). The 2015 survey did not distinguish the ethnicity of respondents, it only gives the data on general attitudes, which thus is not comparable. The survey has found low motivation of pupils and their parents for learning native language. School teachers noted the decrease in the demand for language learning. About half of experts think the main reason of the pupils' attitude was the need to prepare for the state final examination.

In this section, I systematized the available sociological and sociolinguistic data. The census questions were not consistent and there is no reliable survey data, but it is sufficiently sizeable to draw some conclusions about the processes on the ground. The data showed that the language loss continued throughout the post-Soviet period. The intensity of language loss slowed down somewhat during the 1990 os has been accelerating markedly accelerated since the 20oos. The rates of language retention will continue to decline, inter alia, because the share of people with a lack of language knowledge tends to be higher among the younger age cohorts in the age pyramid for all titular groups. Was there any detectable policy impact in this slowdown, as compared to trends triggered by general social factors? The following sections will address this question.

\section{Policy impact}

\section{I. Evaluation of policy impact}

One might argue that the slowdown in assimilationist tendencies in the 1990 and intensified language loss in the 2000 s is to be partly attributed first to the increased provision in policy inputs and outputs and then to their contraction. However, this claim is difficult to verify without taking into consideration the further complexity in the link between the social structure and policy effects.

Impact evaluation is a complex task, because a number of historical and structural variables make it difficult to attribute outcomes to outputs in time 
and space. From a historical perspective, the policy impact on the sociolinguistic situation is protracted in time in terms of policy inputs and outputs, which rarely have immediate effects and rather extend over generations. My hypothesis, which has yet to be proved by a historical study, is that the impact of both the early Soviet nationalities policy of affirmative action and the late Soviet de facto policy of Russification was remarkable also because it emerged in conjunction with major societal changes that transformed the underlying social structure. The post-Soviet policies were not accompanied by major changes comparable to those in the Soviet times, at least not in their ethnic dimension. By historical standards, the policies were pursued too briefly and were too narrow in scope (see Zamyatin, forthcoming).

In Tatarstan, policy outputs largely met the objectives of expansion in the public sphere, according to the evidence provided. However, it was a case of too little, too late: even this was not enough to incur the desired outcomes in official contexts in Tatarstan, as not enough was done to overcome the existing trends embedded in contexts sustained by social, political and economic factors. Political and economic factors constrained policy implementation both at the central and regional levels. Most importantly, the social structure of the vertical ethnic and social stratification sustained the continued trends in assimilation and language shift and, thus, decisively influenced policy outcomes. The Finno-Ugric republics were the only ones among Russia's republics where the shares of the titular groups tended to systematically decrease, and shares of ethnic Russians increase, throughout the post-Soviet period. However, similar processes are ongoing also in Tatarstan, where the knowledge and use of Tatar continue to decrease (State Program of Tatarstan 2013).

From a structural perspective, it is the impact of the Soviet language policy is easier to distinguish. The USSR was nominally a federation but in reality functioned as a unitary state. The Kremlin took into account the situation in republics and the position of their leadership but pursued its policy through a hierarchical structure. Accordingly, one could see how the major policy shifts were reflected in policy outputs. Notably, the late Soviet strategy of building a single Soviet identity included measures for the promotion of Russian. This shift had uneven effects across republics and was detrimental to the position of non-Russian languages, above all, within the RSFSR. Diminished input resulted in an incremental decline in the provision of education and mass media in the titular Finno-Ugric languages. The changed atmosphere and lesser provision led to a decrease in language knowledge 
and use and an increase in negative attitudes towards them. Arguably, it was largely the postponed impact of the 196os Soviet nationalities policy that drove the continued, extensive shift from the titular languages to Russian also into the post-Soviet period (Finno-ugorskie narody 2008: 188).

In contrast, the Russian state in the 1990 functioned as a federation in which the federal center and the regions pursued diverging interests. In this situation, one could speak not about levels of policy but rather about different policies pursued by the federal center and the republics. Policy outcomes depended on the balance of power between central and regional actors. The post-Soviet policy was different from the early Soviet policy of the 1930s in that the Kremlin did not support the republics' revivalist projects in the 1990s, seeing them as a threat to state integrity. The Kremlin did not initially interfere with the regional language policies, but the intensity of the constraints from the centre grew over time. In the 200os, it initiated as part of "bringing regional legislations into line with federal legislation" a wave of amendments to the republics' language and education laws passed in 2000-2001 and 2010-2011 that significantly narrowed the policy scope (see Zamyatin 2013c).

Finally, the Kremlin forced republics to put their "national revival" projects, that is, nation-building agendas on hold, when Russian nationbuilding officially became the strategic goal in late 2012 and assimilationist policy components were strengthened (see Zamyatin 2016a). Thus, in the early 2010s, the language policies in many republics, including the Finno-Ugric ones, were de facto terminated because no separate executive programs were approved, and the statutes of field-specific ministries were changed. There are some exceptions, however: for example, the program on ethnic relations in Udmurtia contains a subprogram entitled "Maintenance and Development of the Languages of the Peoples of the Udmurt Republic" (Zamyatin 2014c, see State Program of Udmurtia 2013). In 2017, the Kremlin insisted on the abolishment of the compulsory teaching of Tatar and other non-Russian languages in republics. The authorities portrayed the teaching of these languages to be at the expense of Russian. The actual target of the measure were those numerous non-Russians who still maintain their ethnic identities but declare Russian as their native language (see Zamyatin 2018a).

Under the general framework of federal legislation, differences between regions still mattered. It was the level of autonomy achieved by such republics as Tatarstan or Bashkortostan that allowed them to pursue assertive 
language policies even after the 200os. Moreover, it was arguably a relatively high level of popular support for nationalism in the republics like Tatarstan or Sakha also after the 2010 s that sustained the scale of cultural activism. In fact, cultural activism under the authoritarian regime is a byword for cultural nationalism. Grassroots activism continued to play the key role in language revival, for example, in school-based language revitalization in Yakutsk (see Chevalier 2017). The control of the republics' policymakers over the decision-making on language issues vis-à-vis the Kremlin and the predominance of ethnic elites among the regional elites ensured the provision of adequate inputs and outputs.

The Finno-Ugric republics did not enjoy such autonomy and largely lacked the control, inter alia, because the titular groups there were in minority situations, represented the lower social strata and expressed a low level of support for nationalism. The unfavourable social structure prevented ethnic elites from taking control over the republics. Only in Mari El did a short-lived wave of mass ethnic mobilization in 1992-1993 enable the policymakers to pursue an assertive policy, which also had greater impact in comparison to the other republics. The lack of control incurred a gap between policy adoption and its implementation, inter alia, because bureaucracy impeded the implementation (see Zamyatin 2014c). Due to the absence or gradual erosion of political will to implement revivalist projects, policies remained much more symbolic than material. Thus, the social structure characterized by the vertical ethnic and social stratification predetermined a narrow scope of policies and their unsatisfying outcomes.

It is possible to link outputs and outcomes by the chronological assumption that, if there were some positive changes, they are probably linked to policy measures, even if "after" does not necessarily mean "because". Official surveys were typically not conducted at regular intervals, with some exceptions. Nonetheless, these exceptions contain some pieces of data in individual republics that provide insight into the link between outputs and outcomes. Further, in the same way as the patterns on policy inputs in the republics tended to correlate with those of outputs, patterns in outputs seemed to correlate with those of outcomes. The data on policy impact are patchy, and it is virtually impossible to substantiate the link between outputs and outcomes beyond a mere correlation. As the patterns across republics were comparable, one can induce from individual cases and argue by analogy about the republics for which there is no respective 
data available that there were similar changes attributable to policy impact, which is again only a probabilistic argument.

\subsection{Policy impact in the Finno-Ugric republics and its limits}

The process of language loss has continued, judging already from the census data on language retention rates. The decrease in language knowledge was characteristic of most groups. In this context, the jump in the share of those Mari who reported Mari as their native language during the $1990 \mathrm{~s}$ is a bit surprising and should be interpreted as a reidentification of what one's native language is rather than an actual increase in knowledge thereof. The relatively stable share of individuals maintaining their linguistic identity throughout the period might in itself have been a policy effect. Similarly, another effect might have been the relatively stable share of individuals with a high language competence, when, throughout the period, more than three quarters of the Mari respondents reported Mari as their native language and stated that they could speak, read and write. However, the role of social factors remained decisive. The measures taken as part of Karelia's language acquisition policy were also extensive, but, in contrast to Mari El, among the Karelian respondents, the share of those who reported a high command of the language decreased by almost a fifth over just a few years in the 2000 .

It seems that policy pursued towards specific target groups has a higher impact than on the target populations in general. A clear pattern of progress is distinguishable in the level of language knowledge among pupils, which could be seen, for example, in the diachronic data on Karelian pupils from the 1990 os and early 2000 s. Furthermore, the data on the pupils is much closer to reality in terms of policy effects. For example, only about half of Mari school graduates reported a high command of the language in 2000, and their share decreased to less than half a decade later. The decrease in the level of language competence could have been anticipated based on the level of policy outputs, as only half of pupils in Mari El and less than a half in the other republics were provided with the opportunity to learn their native languages. The low competence in reading and writing is primarily an outcome of the failure to provide native language teaching.

The data on language use demonstrated that, throughout the period, the titular languages were on the retreat at work and at home. At the same time, there is a stable demand for mass media in the titular languages. 
However, the demand for news in the titular languages under the conditions of bilingualism of the target audience also remains narrow. Yet, if restricted, there was a demand for thematic programs. TV and radio broadcasting are more popular. However, the expert estimations based on survey data showed that the existing editions of printed matters do not satisfy the demand (see Finno-ugorskie narody 2008: 207). In the specific context of school, the data on the use of Karelian among Karelian pupils in the 1990 os demonstrated some positive dynamics, although the trends reversed in the 2000 s.

I have found no data on language use in official contexts. Further, there is only occasional data available on the attitudes towards the use of titular languages in official contexts and typically no systematic data on changes in them. For example, some positive changes in popular attitudes could be detected in Udmurtia between 2000 and 2003 regarding the installation of bilingual signposts and the introduction of language requirements for some professions, although still less than half among the local Russian respondents supported the latter measure (see Etnosotsiologicheskoe issledovanie 2000, Natsionalnye otnosheniia 2003, Vorontsov 2004). The latter is an example of a general majority attitude against the compulsoriness of titular languages.

It was an unintended policy effect that that the predisposition of the Russian-speaking majority against compulsory knowledge, study and official use has hardened over time, as revealed, for example, by the data on attitudes in Mari El. At the same time, it seems to be a policy effect that the support of the titular group for compulsoriness has increased. The data on attitudes are not completely compatible, but one can find certain trends in the indicators. The data on public opinion about the need of the designation of state languages are available only until the mid-199os. Later, the question lost its centrality and ceased to be asked in surveys.

Support for the compulsory study of the titular state language in all schools between 1994 and 2001 increased among the Mari respondents by $2.9 \%$ but decreased among local Russians by $2.4 \%$. The plurality of the Mari respondents (slightly more than a third) supported the need for compulsory knowledge of the titular languages by all inhabitants. Between 1994 and 2001, the share insignificantly increased by $0.4 \%$ among the Mari and decreased by $3.9 \%$ among local Russians. At the same time, the share of those Mari who agreed with the need for compulsory knowledge of the titular languages for leading officials and workers in certain professions 
increased by $11.8 \%$ and the share of those who disagreed with this decreased by $12.7 \%$ (Kudriavtseva \& Shabykov 2002). Furthermore, this support for compulsory knowledge significantly increased between 2001 and 2012 by $18.3 \%$ among the Mari respondents and by $10.6 \%$ among the local Russians. The shares of those who disagreed decreased by $7.2 \%$ among the Mari respondents and by $26.9 \%$, or almost twice over, among the local Russians (Shabykov \& Kudriavtseva 2015).

The increase in support for the compulsoriness of the titular language among the Mari might have been an effect of language promotion efforts in the 1990s. The increase in support in the 2000 s might have actually been driven by resentment of the lack of policy. At the same time, the use of the titular language in mass media and the internet was much more in demand among the Udmurt and Mari respondents, especially among young people, than in official contexts and work environment. In contrast, the Russian respondents in Mari El were more inclined to support the use of the titular languages in official contexts than in social contexts, perhaps because the former did not imply that they would personally be somehow touched.

The cross-regional 2007 survey showed that the policy had not overcome the pessimistic attitudes and more than half among the respondents in all republics did not expect any improvement in the situation of the languages in the future. The majority of respondents thought that the languages had a low or not high enough public value, and the share of individuals who held that view continued to increase, for example in Komi. Yet, the majority of parents of titular nationality still wanted their children to know the language, although only a minority expected them to acquire a high level of command.

While political rhetoric and publicity about policy might have played a role, the public opinion about the sufficiency of policy measures and school capacity might directly reflect the actual effectiveness of policy. Judging by their attitudes, the titular groups in Karelia and Mordovia were more exposed to policy effects in the 200os. In Komi and Udmurtia, the attitudes demonstrate a public perception of insufficient inputs and outputs. In Mari El, public attitudes might have reflected the perception of decreasing policy effects in the 200os, because otherwise the republic's policy figures were better than those of the other republics. More evidence for this is provided by the increase in the perception of language as the main identity marker in the 1990 s and the decrease in the 2000 s. 
In this section, I evaluated policy impact, linking outputs and outcomes. I provided some evidence that in the 1990s, an increase in outputs correlated with the positive dynamics in outcomes, especially in terms of access to native language learning and language knowledge, as demonstrated by the data in the cases of Karelia and Mari El. Since the early 2000 s, a decrease in outputs was also reflected in decreased outcomes, especially in the case of Mari El. In all republics, policies had insufficient inputs and outputs inadequate for the task of inducing the desired outcomes. In general, the policies failed not only to reverse the language shift but even to have any significant impact, and the social structure continued determine the sociolinguistic situation.

\section{Conclusion}

The study has demonstrated that the scale of policy impact was not up to the task of changing the symbolic and interactional order because they were sustained by the existing social structure. The policies faced a number of problems and obstacles that reinforced each other. These included the continued dominance of monolingual ideologies, the prevalence of symbolic over instrumental policy and insufficient policy input in terms of institutional and financial support due to a lack of political support and enthusiasm among implementers, as well as the corresponding inadequate policy outputs that were not able to change the dominant language ideologies. Despite symbolic recognition of their official status, the titular languages remained stigmatized de facto minority languages in public perception. As a result, the policies failed to change the dominant symbolic and interactional order due to their inability to overcome the pattern of one-sided national-Russian.

Why did the policies have such a minor impact? The policies were not able to achieve the desired impact not only because of their narrow inputs and outputs. Suzanne Romaine pointed out that language "policies have negligible impact on home use, which is essential for continued natural transmission of language" (Romaine 2002: 194). She cites Joshua Fishman, who emphasized that this lack of intergenerational language transmission and informal daily life support make a language endangered, not the lack of official status or school teaching (Fishman 1997). She further points at confusion between policy and planning and emphasizes that empowering communities and individuals with language rights does not mean the rights will be used. 
In the Russian context, only a few individual language rights were set in legislation and this was done using not a rights-based approach but rather a top-down policy approach (see Zamyatin 2015). In the early 1990s, the republics' policymakers quite assertively pursued the expansion of the titular languages though the introduction of their compulsory character. However, the principle of non-discrimination on the basis of language prevented the policymakers from interfering with language use of individuals in their private affairs. Public policy could be pursued only in the public sphere. In general, this approach worked in the SSRs with sole state languages, but its application was not calibrated for the ASSRs of Russia that established two state languages but lacked a tradition of official use of the titular languages in the first place.

Under these circumstances, the revivalist policy would have been effective only if reinforced by grassroots initiatives in an active civil society. However, the efforts of authorities were not adequately supplemented by other actors, such as ethnic NGOs (see Zamyatin 2014c). Partly, this might be a Soviet legacy of what Federica Prina (2015: 155) refers to as "an inherent weakness of civil society, with citizens often reluctant to become involved with activism" under the predominant political culture. Another aspect is self-censorship and unwillingness to overstep pre-established boundaries of political discourse (Prina 2015: 156). One should also mention that the authoritarian regime discourages activism and even makes it punishable, for example imposing the fear of losing one's job, and even threatening with violence. Under the conditions of the parochial subject political culture prevailing in the Russian regions, the people did not believe they could influence policy, and elites were subject to relatively little direct influence from apathetic masses.

Popular language attitudes have been a more relevant variable in the case of policy formation in the context of democratization in the 1990s. When comparing the indicators across the periods, one has to note that the data for the early 1990s also reflected the period of high activities of national movements, which in the Finno-Ugric republics with their low popular support for nationalism, however, never reached the stage of mass ethnic mobilization, except for a short time in Mari El. Nevertheless, policymakers were able to include the compulsory teaching of the titular state languages in the laws, despite the low overall popular support for this measure in Komi, Mari El and Mordovia. Hence, these were beliefs and attitudes of the elites that mattered more than popular language attitudes when it came to policy formation. 
Policy input depended on the ability of ethnic pressure groups to bargain for their vision on language issues among other segments of regional elites (see Zamyatin 2014c: 229). Public debate in the mass media was the arena for expressing common attitudes, but media coverage as well as the results of surveys on popular opinion were often used by both the authorities and interest groups to justify their positions (see Zamyatin 2013c: 140141). By the early 200os, mass politics everywhere had given way to elite politics. If a consensus was reached among the elite, public opinion could be ignored, as in the case of the introduction of compulsory study of the titular languages. However, in the case of an absence of consensus, a side effect of the assertive policy was that it provoked resentment among the local Russians and especially among the regional Russian elites, as in Mari El. In the 200os, the resentment resulted in a backlash, when the new, predominantly Russian ruling elite put the policy on hold in Mari El, or when the bureaucracies impeded policy implementation in the other republics (see Zamyatin 2014c). From the perspectives of time and place, the regime change at the central and regional levels was followed by a narrowing of policy scope and hindered implementation.

However, the problem of the linkage between elites and masses is more complex. In the 1990s, this linkage could be characterized as a system of state corporatism, when one peak ethnic organization was officially recognized as an interest group expressing the interests of the titular group. In the 200os, state corporatism was easy convertible under the authoritarian tendencies into state control over the peak organization, for example, through centralized control of funding (see Prina 2015: 168-175). In these circumstances, the policy design itself gave third parties little autonomy and accepted them only as minor partners in policy formation. The topdown policy itself left little room for active participation of third sector organizations, that is, "a limited perceptiveness of civil society initiatives" (Prina 2015: 156). It was not a user-oriented policy, because the concerns of the policy users were not considered properly.

The measures were directed mostly at status planning and acquisition planning and often implied compulsoriness. A contrast in the perceptions of policymakers and public perceptions about the official and social functions of languages could be seen in the data on the hierarchy of public opinion about measures needed in order to achieve the state of official bilingualism and to raise the prestige of titular languages. As it was shown, users were more interested in the development of mass media in the language than 
in compulsory study of titular languages in school, and much less interested in their official use by public authorities and in the work environment. Only later did the language planners start to pay more systematic attention to prestige planning and public attitudes, and to promote the languages locally (Zamyatin 2014c). These measures found some resonance among grassroots activists. However, the scale of cultural activism remained much lower than in some other places and inadequate for the task.

Therefore, the policy evaluation has shown that the populations, including the titular groups and their elites themselves, were not ready for a change in the social status of languages, because there was no corresponding change in the social structure. The strategy of expanding the compulsoriness of the titular languages was a forced choice of the titular elites because it was a much more difficult task to encourage the free use of languages given the prevailing nihilist attitudes among the titular groups. In any case, it is nearly impossible to expand the practical use of a language with lower prestige and status in a situation of functional distribution of diglossia (Zamyatin 2015). Under the conditions of broken intergenerational language transmission within most families, the erosive trends of language shift and ethnic assimilation also continued throughout the post-Soviet period despite policy efforts.

Konstantin Zamyatin

Durham University ER254, Elvet Riverside II

Durham DH1 3 DB United Kingdom konstantin.i.zamyatin@durham.ac.uk 


\section{Notes}

1 Research for this article was made possible by a scholarship from the Finnish Cultural Foundation.

\section{References and Sources}

\section{References}

Anderson, James 2010: Public Policymaking: An Introduction. 7th Edition. Wadsworth: Cengage Learning.

Chevalier, JoAn F. 2017: School-based Linguistic and Cultural Revitalization as a Local Practice: Sakha Language Education in the City of Yakutsk, Russian Federation. Nationalities Papers 45 (4): 613-631.

De Korne, Haley 2012: Improving Language Policy and Planning Through Evaluation: Approaches to Evaluating Minority Language Policies. Working Papers in Educational Linguistics 27 (2): 38-55.

Dye, Thomas 2001: Top-down Policy-Making. New York \& London: Chatham House.

Dye, Thomas 2013: Understanding Public Policy. 14th Edition. Boston: Pearson.

FEDINA 2016 = Федина М. С.: Финно-угорские языки Российской Федерации в электронном информационном пространстве: опыт, проблемы и перспективы. Финно-угорский мир 3: 111-121.

Fishman, JoshUA 1991: Reversing Language Shift. Theoretical and Empirical Foundations of Assistance to Threatened Languages. Clevedon: Multilingual Matters.

Fishman, JoshUA 1997: Maintaining Languages. What Works and What Doesn't. - Gina Cantoni (ed.), Stabilizing Indigenous Languages. Flagstaff, Ariz.: Northern Arizona University. 186-198.

Gabdrahmanova et AL. 2016 = Габдрахманова Г., Махмутов 3. \& Сагдиева Э.: Этноязыковой ландшафт городов Республики Татарстан. Государственные языки Республики Татарстан: множественность измерений. Сборник очерков. Под ред. Г.Ф. Габдрахмановой, Г.И. Макаровой, А.Р. Мухаметзяновой. Казань: Институт истории им. Ш. Марджани АН РТ.

Gabusheva 2013 = Габушева Г. И.: Функционирование государственных языков Республики Коми: к 2о-летию принятия Закона $\mathrm{PK}$ «О государственных языках Республики Коми». Государственные языки финно-угорских регионов: реалии современности: сборник статей. Отв. ред. А.Н. Рассыхаев. Сыктывкар: Издательство «КРТ».

Gorenburg, Dmitry 2003: Minority Ethnic Mobilization in the Russian Federation. New York: NY Cambridge University Press.

Gorenburg, Dmitry 2005: Tatar Language Policies in Comparative Perspective: Why Some Revivals Fail and Some Succeed. Ab Imperio 1: 257-284.

Grin, FrançOIS 2003: Language Policy Evaluation and the European Charter for Regional or Minority Languages. New York: Palgrave Macmillan. 
Guboglo \& Smirnova $2001=$ Губогло M. Н. \& Смирнова С. К.: Феномен Удмуртии. Парадоксы этнополитической трансформации. Москва-Ижевск: ИЭА РАН.

Hill, Michael \& Hupe, Peter 2002: Implementing Public Policy. London: SAGE Publications.

Horowitz, Donald 1985: Ethnic Groups in Conflict. Berkeley and Los Angeles: University of California Press.

HUdAVERDIAN 1998 = Худавердян В. Ц.: Социология чтения национальной книги // Социологические исследования. № 7: 100-108.

Iskнакоva $2002=$ Исхакова 3. А.: Функциональное взаимодействие татарского и русского языков в современном Татарстане // Язык и этнос на рубеже веков. Казань: Магариф,. 13-41.

Johnson, David 2013: Language Policy. Basingstoke: Palgrave Macmillan.

KLementiev 2013 = Клементьев Е. И.: Языковые процессы в Карелии на примере карелов, вепсов, финнов. Петрозаводск: КарНЦ РАН.

KondRASHKINA 2008 = Кондрашкина Е. А.: Динамика функционального развития марийского языка. Москва: Институт языкознания РАН.

Kudriavtseva \& Shaвyкov 2002 = Р. Кудрявцева \& В. Шабыков: Республика Марий Эл: Языковая ситуация и языковая политика в сбере образования. Русский язык в формировании межэтнической солидарности (региональные аспекты языковой ситуации в России и ближнем зарубежье). Москва: Изд-во РУДН.

LallukKa, Seppo 1990: The East Finnic Minorities in the Soviet Union. An Appraisal of the Erosive Trends. Helsinki: Annales Academiæ Scientiarum Fennicæ, Humaniora, vol. 252.

Mironova 2012 = Миронова, Н. П.: Коми язык, этническая самоидентификация и вопросы региональной политики в Республике Коми. Этнополитическая ситуация в России и сопредельных государствах в 2011 году: ежегод. докл. Сети этнол. мониторинга и ран. предупреждения конфликтов. Москва: ИЭА РАН. 216-222.

Musina, Rozalinda 2004: Ethnosocial Development and Identity of Contemporary Tatars. Anthropology \& Archeology of Eurasia 43(2): 77-93.

Prina, Federica 2015: National Minorities in Putin's Russia: Diversity and Assimilation. London: Routledge.

Romaine, Suzanne 2002: The Impact of Language Policy on Endangered Languages. International Journal on Multicultural Societies 4(2): 194-212.

Sabatier, Paul A. (ed.) 2007: Theories of the Policy Process. Boulder, CO: Westview Press.

SEmionov 2008 = Семенов Ю. В.: О языковой политике. Этноконфессиональная ситуация в Приволжском федеральном округе. Бюллетень Сети этнологического мониторинга и раннего предупреждения конфликтов № 135.

Sнавукоv et al. 2014а = В. Шабыков, Р. Кудрявцева \& Д. Казанцев: Проблема «государственного» двуязычия в восприятии обучающейся молодежи Республики Марий Эл // Исторические, философские, политические и юридические науки, культурология и искусствоведение. Вопросы теории и практики. № 2 (40): в 2-Х ч. Ч. 1: 204-207.

ShaвүкоV ET AL. 2014b = B. Шабыков, Р. Кудрявцева \& Д. Казанцев: Язык как этническая ценность (к вопросу об этнической природе общественного сознания населения Республики Марий Эл в начале 2010-х годов). Исторические, филособские, политические и юридческие науки, культурология и искусствоведение. Вопросы теории и практики. № 2 (40): в 2-х ч. Ч. 2: 207-210. 
Shabykov \& Kudriavtseva $2015=$ В. Шабыков \& Р. Кудрявцева: Проблема витальности марийского языка (социолингвистический аспект). Исторические, философские, политические и юридические науки, культурология и искусствоведение. Вопросы теории и практики № 8-1 (58): 203-206.

Sharov 2002 = Шаров В. И.: Республика Марий Эл. Этноконфессиональная ситуация в Приволжском федеральном округе. Бюллетень Сети этнологического мониторинга и раннего предупреждения конфликтов № 4 о.

SHAROV 2008 = Шаров В. И.: О перспективах развития государственных языков // Этноконфессиональная ситуация в Приволжском федеральном округе. Бюллетень Сети этнологического мониторинга и раннего предупреждения конфликтов № 135 .

Shilov 2003 = Шилов Н.: Республика Мордовия. На пути к переписи. Под ред. В.А. Тишкова. Москва: Авиаиздат. 251-276.

SHKLIAEV 1998 = Шкляев Г. К.: Межнациональные отношения в Удмуртии: опьт историко-психологического анализа. Ижевск: УдмИИЯЛ.

Smirnova 2002 = Смирнова С. К.: Феномен Удмуртии. Этнополитическое развитие в контексте постсоветских трансформаций. Москва-Ижевск: ИЭА PAH.

Spolsky, Bernard 2004: Language Policy: Key Topics in Sociolinguistics. Cambridge: Cambridge University Press.

SpOlsky, BernARD 2009: Language Management. Cambridge: Cambridge University Press.

VAVILIN 1989 = Вавилин В. Ф.: Количественная оценка современных этнокультурных проиессов в Мордовской АССР (сельское население). Саранск: Изд. Сарат. ун-та. Саран. фил.

Verba, Sidney \& Gabriel Almond 1963: The Civic Culture. Princeton: Princeton University Press.

Vlasova 2016 = Власова T. А.: Этнокультурное образование в школах Удмуртии: социологический очерк. Ижевск: Институт компьютерных исследований.

Vorontsov 2004 = Воронцов В. С.: О деятельности министерства национальной политики. Этноконфессиональная ситуация в Приволжском федеральном округе. Бюллетень Сети этнологического мониторинга и раннего предупреждения конфликтов № 70.

Vorontsov 2013 = Воронцов В. С.: Реализация языковой политики в Удмуртии и общественные инициативы. Гражданские инициативы в сбере этнической политики. Возможности посредничества гражданских структур в деле предупреждения и урегулирования этнических конфликтов. Под ред. В. Зорина, В. Степанова. Москва: ИЭА РАН. 157-168.

WILLIAMS ET AL. 2008 = Этническое и языковое возрождение в Удмуртии: от политики к культурному многообразию: коллективная монография. Под ред. К. Уильямса, А. Баранова, Л. Федоровой, В. Воронцова. Ижевск: Издательство Удмуртского университета.

Zamyatin, Konstantin 2012a: The Education Reform in Russia and its Impact on Teaching of the Minority Languages: an Effect of Nation-Building? Journal on Ethnopolitics and Minority Issues in Europe 11 (1): 17-47. 
Zamyatin, Konstantin 2012b: From Language Revival to Language Removal? The Teaching of Titular Languages in the National Republics of Post-Soviet Russia. Journal on Ethnopolitics and Minority Issues in Europe 11 (2): 75-102.

Zamyatin, Konstantin 2012c: The Finno-Ugric Languages in Russian Education: Changing Legal-Institutional Framework and Falling Access to Native Language Study. Études finno-ougriennes 44: 197-272.

Zamyatin, Konstantin 2013a: Sovereignisation and State Languages: Early Formation of Language Policy of Russia’s Finno-Ugric Republics under the Conditions of the USSR Disintegration. Finnisch-Ugrische Mitteilungen 36: 123-165.

Zamyatin, Konstantin 2013b: Finno-Ugric Republics and Their State Languages: Balancing Powers in Constitutional Order in the Early 1990s. Journal de la Société Finno-Ougrienne 94: 337-381.

Zamyatin, Konstantin 2013c: Official Status As a Tool of Language Revival? A Study of the Languages Laws in Russia's Finno-Ugric Republics. Journal of Ethnology and Folkloristics 7 (1): 125-153.

Zamyatin, Konstantin 2014a: An Official Status for Minority Languages? A Study of State Languages in Russia's Finno-Ugric Republics. Helsinki: Finno-Ugrian Society.

Zamyatin, Konstantin 2014b: Deficiencies of Official Bilingualism in Russia's FinnoUgric Republics: A Legal Perspective. Finnisch-Ugrische Forschungen 62: 399-447.

Zamyatin, Konstantin 2014c: "Maintaining and Developing the Languages": Participation in Decision-Making and Support for Language Revival in Russia’s FinnoUgric Republics. Finnisch-Ugrische Mitteilungen 38: 193-253.

Zamyatin, Konstantin 2015: The Evolution in Language Ideology of Post-Soviet Russia. The Fate of the State Languages of the Republics. - Heiko F. Marten, Michael Rießler, Janne Saarikivi \& Reetta Toivanen (eds), Cultural and Linguistic Minorities in the Russian Federation and the European Union. London: Springer. 279-313.

Zamyatin, Konstantin 2016a: Russian Political Regime Change and Strategies of Diversity Management: From a Multinational Federation towards a Nation-State. Journal of Ethnopolitics and Minority Issues in Europe (1): 19-49.

Zamyatin, Konstantin 2016b: Russia's Minority Education and the European Language Charter. - Janne Saarikivi \& Reetta Toivanen (eds), Linguistic Genocide or Superdiversity: New and Old Language Diversities. Clevedon: Multilingual Matters. 251-284.

Zamyatin, Konstantin 2016c: An Ethnopolitical Conflict in Russia’s Republic of Mari $\mathrm{El}$ in the 2000s: The Study of Ethnic Politics under the Authoritarian Turn. FinnischUgrische Forschungen 63: 214-253.

Zamyatin, Konstantin 2018a: A Russian-Speaking Nation? The Promotion of the Russian Language and Its Significance for Ongoing Efforts at the Russian NationBuilding. - François Grin \& Peter A. Kraus (eds), The Politics of Multilingualism: Linguistic Governance, Globalisation and Europeanisation. Amsterdam: John Benjamins. 39-64.

Zamyatin, Konstantin 2018b: Official Bilingualism in Ethnic Republics of Russia and Language Attitudes. Paper presented at the symposium Multilingualism in PostSoviet Area and Language Attitudes, University of Edinburgh, UK, 15 June 2018.

Zamyatin, Konstantin (forthcoming): Language Policy of Russia: Uralic Languages. - J. Laakso, E. Skribnik \& M. Bakró-Nagy (eds), Oxford Guide of Uralic Languages. Oxford: Oxford University Press, 16 p., in press. 
YANALOv 2000 = Яналов В. Г.: “Марий Эл Респубикысе йылме-влак нерген” 200о2005 ийлан кугыжаныш программым илышыш пуртышаш законын проектше нерге. Проблемь развития марийского языка как государственного: сб. докл. и сообщ. респ. науч.-практ. конф. Галкин И.С. (науч. ред.). Йошкар-Ола: МарНИИ. 14-17.

\section{Sources}

Etnosotsiologicheskoe issledovanie 2000 = Этносоциологическое исследование, посвященное изучению состояния межнациональных отношений в Удмуртской Республике. Ижевск: Архив Министерства национальной политики Удмуртской Республики.

Etnokulturnoe obrazovanie $2010=$ Этнокультурное образование. Методы социальной ориентации российской школы. Под ред. В. В. Степанов. - М.: ИЭА РАН.

Finno-ugorskie narody $2008=$ Финно-угорские народь России: вчера, сегодня, завтра. Под ред. А. Конюхова. Сыктывкар: Коми Войтыр.

Finno-ugorskii mir $2012=$ Финно-угорский мир. Информационно-статистический сборник. Под ред. В. Маркова и др. Сыктывкар: Комистат.

Implementation Report 2014 = Доклад о реализации Государственной программы Удмуртской Республики «Этносоциальное развитие и гармонизация межэтнических отношений в 2013-2020 годах» в 2014 году. Министерство национальной политики Удмуртской Республики.

Kulturnoe stroitelstvo 1940 = Культурное строительство СССР (Статистический сборник). Москва: Госпланиздат.

Long-term Program 2009 = Долгосрочная республиканская целевая программа "Сохранение и развитие государственных языков Республики Коми (20102012 годы)”, утверждена Постановлением Правительства Республики Коми от 14.09.2009 года №258.

Mezhetnicheskie otnosheniia 2016 = Межэтнические отношения и этнокультурное образование в регионах России. Под ред. В. А. Тишкова и В. В. Степанова. Москва: ИЭА РАН.

Mezhnatsionalnye otnosheniia $1995=$ Межнациональные отношения в Республике Марий Эл (по материалам сочиологического исследования). Под ред. В. Шабыкова, В. Соловьева, С. Исанбаева. Йшкар-Ола: МарНИИ.

Mezhnatsionalnye otnosheniia $2002=$ Межнациональные отношения в Республике Марий Эл (материалы социологического исследования 2001 года). Научно-статистический бюллетень. Под ред. В. Шабыкова. Йошкар-Ола: МарНИИ.

Naselenie Rossii 2013 = Население России 2010-2011: Восемнадиатый-девятнадиатый ежегодный доклад. Под ред. А.Г. Вишневского. Москва: НИУ ВШЭ.

Natsionalnye fondy $2007=$ Национальные фонды: состояние, проблемы, перспективы: результаты социологического исследования. [Авт.-сост. Л. А. Рассохина; ред. С. А. Грибова]. - Саранск: Нац. б-ка им. А. С. Пушкина.

Population Census 1989 = Национальный состав населения РСФСР: по данным Всесоюзной переписи населения 1989 года. Москва: Госкомстат РСФСР. 
Population Census 2002 = Национальный состав населения и владение языками, гражданство. Итоги Всероссийской переписи населения 2002 года. Том 4 (1). Москва: Статистика России.

Population Census 2010 = Национальный состав населения по субъектам Российской Федерации: Приложение 7. Информационные материаль об окончательных итогах Всероссийской переписи населения 2010 года. Available at: <http:// www.gks.ru/free_doc/new_site/perepis2010/perepis_itogi1612.htm>

Natsionalnye otnosheniia 2003 = Национальные отношения в Удмуртской Республике в 2003 году. Ижевск: Архив Министерства национальной политики Удмуртской Республики.

Opros 1996 = Республиканский опрос «Общественное мнение населения Республики Коми по проблемам государственности и суверенитета». Сыктывкар: Архив Министерства национальной политики Республики Коми.

Opros 2004 = Республиканский опрос «Я и мой народ». Сыктывкар: Архив Министерства национальной политики Республики Коми.

Predvaritelnye itogi 2007 = Предварительные итоги мониторингового исследования «Состояние, развитие и использование карельского языка в Республике Карелия» // Развитие карельского языка в Республике Карелия: состояние, проблемы, перспективы. Материаль Республиканской научно-практической конференции 26-27 июня 2007 года. Петрозаводск: Verso. 77-87.

Sotsiologicheskie issledovaniia 2013 = Социологические исследования межнациональных и межконфессиональных отношений: Материалы межрегиональной научно-практической конференции т июня 2012 г. О. В. Орлова, В. И. Шабыков (науч. ред.). Йошкар-Ола: МарНИИ.

State Program of Udmurtia 2013 = Государственная программа Удмуртской Республики «Этносоциальное развитие и гармонизация межэтнических отношений в 2013-2020 годах», утверждена Постановлением Правительства Удмуртской Республики от 19.08.2013 года №372.

State Program of Tatarstan 2013 = Государственная программа Республики Татарстан «Сохранение, изучение и развитие государственных языков Республики Татарстан и других языков в Республике Татарстан на 2014-2020 годы», утверждена Постановлением Кабинета Министров Республики Татарстан от 25.10.2013 № 794 .

Yazykovoe raznoobrazie $2010=$ Языковое разнообразие в Российской Федерации: проблемы и перспективы. Парламентские слушания. Информационный бюллетень Государственное строительство и конституционные права граждан, № 24. Москва: Аппарат Государственной Думы. 